\title{
Slope instabilities at an active continental margin: large-scale polyphase submarine slides along the northern Peruvian margin, between $5^{\circ} \mathrm{S}$ and $6^{\circ} \mathrm{S}$
}

\author{
Anne Duperret ${ }^{\text {a,b }}$, Jacques Bourgois ${ }^{\text {a }}$, Yves Lagabrielle ${ }^{\mathrm{b}}$, Erwin Suess ${ }^{\mathrm{c}}$ \\ a I.N.S.U.-C.N.R.S. and Université Pierre et Marie Curie, Département de Géologie sédimentaire, Laboratoire de \\ Géodynamique Tectonique et Environnement, Boitte 119, tour 26, E4, 4 place Jussieu, 75252 Paris cedex 05, France \\ ${ }^{b}$ I.N.S.U.-C.N.R.S. and Université de Bretagne Occidentale, Département des Sciences de la Terre, 6 avenue Le Gorgeu, \\ 29287 Brest cedex, France ${ }^{1}$ \\ ' Forschungsinstitut für Marine Geowissenschaften (GEOMAR), Christian-Albrechts Universität, \\ 24148 Wischofstraße 1-3, Kiel, Germany
}

Received 29 August 1994; revision accepted 12 December 1994

\begin{abstract}
A mega-submarine slide was evidenced along the Peruvian margin during a Seabeam survey of the R/V Charcot (Bourgois et al., 1986). The debris-slide was initially interpreted as the result of the slope failure occurring along a seaward curved scarp, and extending from east to west, along the line of maximum slope. Complementary bathymetric data obtained from the R/V Sonne survey conducted to the north and to the south of the previous surveyed area has resulted in the identification of large-scale polyphase submarine slides involving a total surface of about $1000 \mathrm{~km}^{2}$, between latitudes $5^{\circ} 15^{\prime} \mathrm{S}$ and $6^{\circ} 05^{\prime} \mathrm{S}$. Using Seabeam and Hydrosweep multibeam echosounder data in combination with deep-sea submersible observations, three distinct slope-failure types related to three main stages have been revealed. The three sliding phases occurred roughly along the same trend, orientated $\mathrm{N} 230^{\circ}$, and are therefore mainly controlled by the $\mathrm{N} 80^{\circ}$ orientation of the subducting Nazca plate. (1) The first phase of slope failure is documented by a debris-avalanche deposit, which extends from the lower slope down to $5 \mathrm{~km}$ within the trench floor. The deposit originates from the northern wall of a wide valley located along the upper slope. (2) The second phase of slope failure is characterized by a debris-avalanche, with a crescent-shaped scar, located along the middle slope and a hummocky deposit covering the lower slope and extending up to $10 \mathrm{~km}$ across the trench. The volume of rock involved in this event is estimated to some $250 \mathrm{~km}^{3}$. The slope failure is assumed to be related to an oversteepening of the middle slope induced by a rollover deformation. (3) The third phase of slope failure corresponds to a translational sliding block and a toppling block with volumes of $6 \mathrm{~km}^{3}$ and $13 \mathrm{~km}^{3}$, respectively. The seismic energy produced during the seismic cycle has greatly increased fracturation and fluids buildup along the area previously weakened by a rollover fold. A restricted N-S folding is observed in the vicinity of the trench, to the north of the two debris-avalanche deposits. It may have formed in relation to the local compression limited to the subduction of the Nazca plate. Sliding and folding thus document the paradox between the compressive regime in the lower plate and the extensional regime in the upper part of the upper plate.
\end{abstract}

\footnotetext{
${ }^{1}$ Address for correspondence.
} 


\section{Introduction}

Most of the large-scale submarine landslides recognised worldwide occur either along intraplate volcanic alignments or along active continental margins. They include landslides along the steep submerged volcanic slopes of the Hawaiian islands (Lipman et al., 1988; Moore et al., 1989), the large landslides from Tristan da Cunha (South Atlantic island) and from $\mathrm{El}$ Hierro (Canary islands) described by Holcomb and Searle (1991), the volcanic debris-avalanche along the submerged flank of the Fournaise volcano off the Reunion island (Lénat et al., 1989; Cochonat et al., 1990), the giant submarine slide on the northern slope of Puerto Rico island (Schwab et al., 1991) and the giant submarine slump along the northern Chile continental slope (Li et al., 1991). All of the examples listed above are significant because of their large-scale submarine instabilities within consolidated materials.

Topographic features indicating a mega submarine slide were mapped along the northern Peruvian margin, during the SEAPERC cruise in 1986 (Bourgois et al., 1986). Bathymetric data collected offshore Paita, between $5^{\circ} 25^{\prime}$ and $5^{\circ} 50^{\prime} \mathrm{S}$, using the multibeam echo-sounder Seabeam allowed to document one seaward facing scarp located along the middle part of the margin. Meanwhile the lower part of the slope shows a hummocky topography exhibiting the typical signature of a debris-slide deposit, which extends down to the Peru Trench axis (Bourgois et al., 1986, 1988). The scarp has been interpreted as the results of slope failure which was assumed to occur as a single catastrophic event. Such event most likely induced a tsunamogenic wave along the northern coast of Peru (Von Huene et al., 1989). Subsequently, deepsea dives (NAUTIPERC cruise, 1991) were performed in the same area with the submersible Nautile in order to better understand the tectonic and gravitational processes that have affected this area (Bourgois et al., 1993).

In 1992, a hydrosweep survey was carried out with the R/V Sonne north and south of the area previously surveyed by Seabeam and the data were merged with these previous bathymetric data. The aim of this article is to describe the compilation of data from these two different techniques of multi-beam bathymetric surveys. As discussed below, the results show the occurrence of several kilometre-sized arcuate scarps related to several mega submarine slides instead of one single slide as proposed previously (Bourgois et al., 1988, 1993; Von Huene et al., 1989). In order to discuss the different processes involved in such successive slope failures, a detailed analysis of the tectonic framework needs to be conducted first. A better knowledge of the general tectonic setting and the subsequent state of stress of the margin will allow us to a better understanding of the significance of morphological features described along the margin in terms of slope instabilities.

\section{Previous studies offshore Paita}

\subsection{Tectonic setting}

The northern Peruvian margin marks the boundary between the South American and Nazca plates (Fig. 1). The Nazca plate is subducting beneath the South American plate along a N82 ${ }^{\circ}$ direction with a convergence rate varying from $9 \mathrm{~cm} / \mathrm{yr}$ (Minster and Jordan, 1978, Chase, 1978) to $11 \pm 0.8 \mathrm{~cm} / \mathrm{yr}$ (Pardo-Casas and Molnar, 1987) and $8 \pm 0.5 \mathrm{~cm} / \mathrm{yr}$ (De Mets et al., 1990). Between $4^{\circ} \mathrm{S}$ and $6^{\circ} \mathrm{S}$, the distance from the trench axis to the coastline varies from 65 to $110 \mathrm{~km}$ (Fig. 1) (Thornburg and Kulm, 1981). It appears as one of the narrowest plate-boundaries of the Andean convergent margin, with a continental shelf ranging from $10 \mathrm{~km}$ to $40 \mathrm{~km}$ in width and a continental slope with a steep topographic profile, characterized by an average slope gradient of $5^{\circ}$.

\subsection{The CDP3 line}

During the Nazca plate project, one 24-channelcommon-depth-point seismic line (CDP3) was shot on the landward slope of the Peru Trench between $5^{\circ}$ and $6^{\circ} \mathrm{S}$ offshore Paita (Kulm et al., 1981) (Fig. 5). The interpretation of the CDP3 profile allowed Shepherd and Moberly (1981) and Miller 


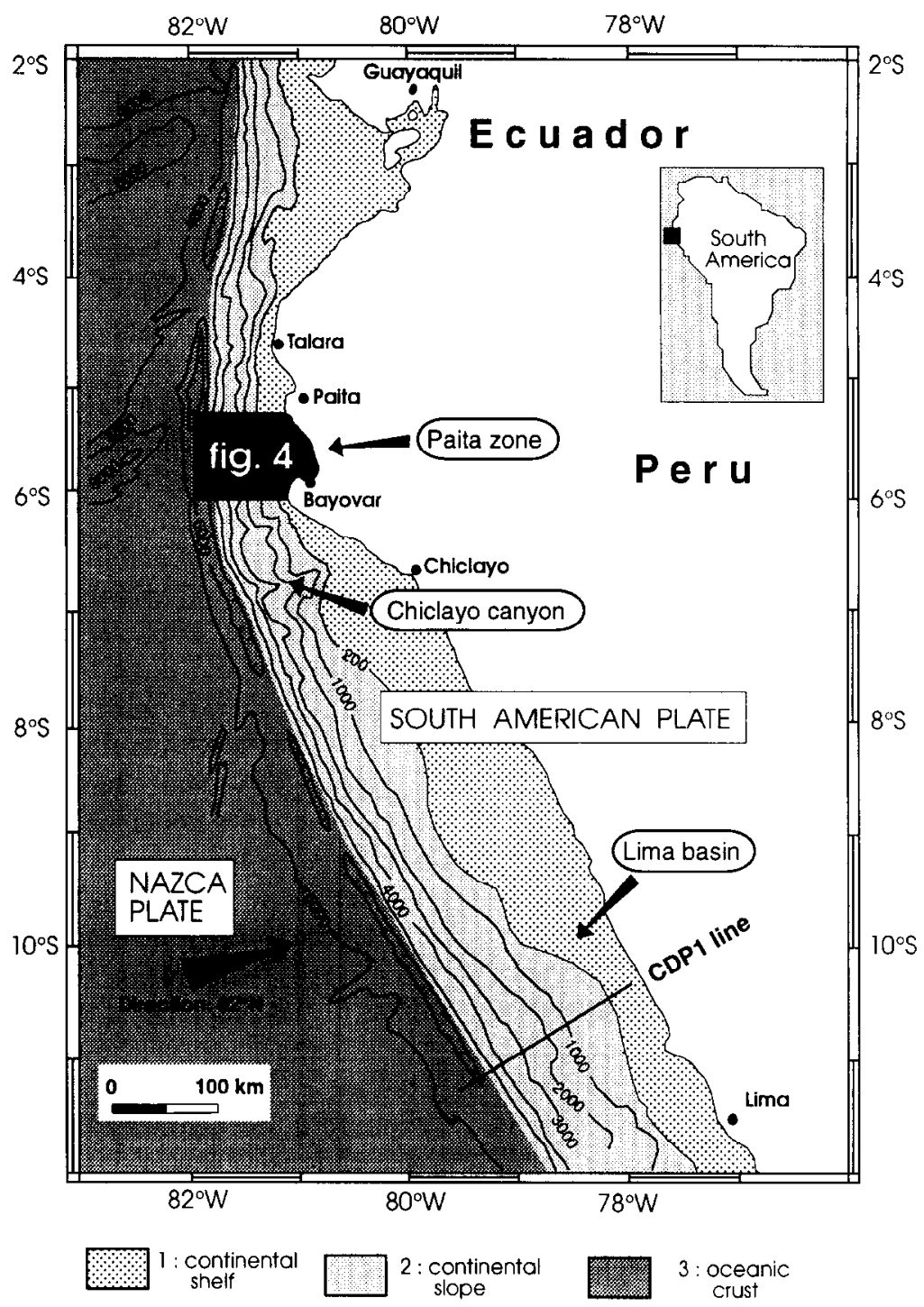

Fig. 1. Simplified bathymetry along the northern Peruvian margin. Isobaths every $1000 \mathrm{~m}$. Black arrow: direction of convergence between Nazca plate and South American plate. Black area: location of the surveyed area offshore Paita.

et al. (1986) to conclude that the upper slope is deformed by normal faulting, whereas the lower and the middle slope are exhibiting the diffraction pattern of an accretionary prism. They assumed that the transition zone between tensional and compressional tectonic areas should thus occur within the middle slope area. In 1986 these seismic data were completed by a $40 \mathrm{~km}$ wide swath of Seabeam bathymetry centered around the CDP3 line. Simultaneously four multichannel seismic profiles were acquired perpendicularly to the CDP3 line (Bourgois et al., 1986). The bathymetric data revealed the occurrence of two prominent curved scarps: the 400-700 $\mathrm{m}$ high upper slope scarp (USS) separating the upper slope from the middle slope area, and the 1000-1200 m high middle slope scarp (MSS), located $10 \mathrm{~km}$ seaward along the middle slope. The lower slope is characterized by a chaotic topography with highs and lows without preferred orientation, suggesting an accumulation 
of mass-wasted debris from the MSS (Bourgois et al., 1986, 1988, 1993; Von Huene et al., 1989; Duperret et al., 1993). From the interpreted additional seismic data, it was suggested that the USS represents the scarp of a detachment fault dipping $45^{\circ}$ seaward (Bourgois et al., 1988). After reprocessing of the CDP3 line, including pre-stack migration (Von Huene and Miller, 1988), the middle part of the slope has been interpreted as a landward tilted block rotated along a major detachment fault, with massive collapse of the seaward part of the block (Von Huene et al., 1989). Subsequently the mass-wasting covered the accretionary prism of the lower part of the slope (Bourgois et al., 1988; Von Huene et al., 1989). The deep-sea dives of the submersible Nautile along the USS and MSS have shown the middle slope as a broad rollover fold formed in association with the detachment fault located along the USS. The massive collapse originating from the MSS occurred thus by oversteepening of the seaward flank of the rollover fold (Bourgois et al., 1993).

\subsection{Subsidence of the Peruvian margin}

According to Kulm et al. (1984, 1988), Suess et al. (1988), Von Huene et al. (1988), and Resig et al. (1989), the Peruvian margin has undergone massive subsidence, since at least $6 \mathrm{Myr}$ (Bourgois et al., 1990). Normal faulting has been widely observed along the Peruvian margin, and commonly affects the upper part of the slope, as revealed by numerous seismic and bathymetric lines acquired between $4^{\circ}$ and $12^{\circ} \mathrm{S}$ (e.g. Shepherd and Moberly, 1981; Hussong and Wipperman, 1981; Thornburg, 1985).

As noted by Von Huene and Scholl (1991), the subsidence of continental margins of the order of several kilometers can involve several tectonic processes, such as a crustal thinning by listric normal faulting, subduction erosion of the upper plate or a change in the configuration of the subduction plane in relation with changes in the geometry of the lower plate.

Subsidence rates have been estimated along two transects of the Peruvian margin. A first estimation has been obtained by a combination of the analysis of the CDP1 multichannel seismic profile and the results of ODP Leg 112. The CDP1 MCS line is located across the Lima basin at $11^{\circ} \mathrm{S}$ (Von Huene and Miller, 1988) (Fig. 1). During the ODP Leg 112,5 sites were drilled along the CDP1 profile that constrain the subsidence history of the Peruvian margin (Von Huene et al., 1988). At Site 688 , located $20 \mathrm{~km}$ landward of the trench axis, a basal Pliocene sequence was drilled. It includes finely laminated coastal upwelling facies that are restricted to deposition in water depth ranging from 150 to $500 \mathrm{~m}$. Their recovery indicates $3.5-4 \mathrm{~km}$ of subsidence during the past $5-6 \mathrm{Myr}$, at a rate of $675 \mathrm{~m} / \mathrm{Myr}$ (Von Huene et al., 1988; Bourgois et al., 1990). This is consistent with subsidence rates of 350 to $650 \mathrm{~m} / \mathrm{Myr}$ documented from foraminifera assemblages of samples dredged upslope in the Lima basin (Kulm et al., 1984, 1988). Along the same transect, Von Huene and Lallemand (1990) and Von Huene and Scholl (1991) considered that the Incaic-Quechua unconformity $(20 \mathrm{Ma})$ separating Neogene and Paleogene units documents the subsidence during the past $20 \mathrm{Myr}$.

The second estimation has been obtained along the Chiclayo canyon, which is located around $7^{\circ} \mathrm{S}$ (Fig. 1). Calculation is based on three deep-sea dives of the submersible Nautile conducted during the NAUTIPERC cruise (Sosson et al., 1994). During this survey, the Andean metamorphic basement is exposed in deeply incised canyon. It was sampled at locations $19 \mathrm{~km}$ and $40 \mathrm{~km}$, respectively, landward from the trench axis. According to Sosson et al. (1994), open marine sediments of early Pliocene age (5.1-5.3 Ma) unconformably overlying metamorphic rocks were also sampled at these two sites. The same unconformity is assumed to extend onshore along the Sechura basin. Subsidence of $2-3.5 \mathrm{~km}$ occurred during the last 5.1-5.3 Myr at a rate of 452-713 m/Myr (Sosson et al., 1994). This is in good agreement with the subsidence rates documented along the CDP1 transect (Kulm et al., 1988; Von Huene et al., 1988; Bourgois et al., 1990).

\section{The subduction-erosion}

Many authors have explained the large subsidence of the Peruvian margin by a process of subduction erosion, caused by the tectonic erosion 
of the lower face of the continental margin by friction along the subduction plane (e.g. Scholl et al., 1980; Hussong and Wipperman, 1981; Aubouin et al., 1984; Von Huene and Scholl, 1991). Along the CDP1 line, the volume of removed material varies from 485 to $890 \mathrm{~km}^{3} / \mathrm{km}$ along trench during the past 4-6 Myr, which yields a rate of subduction-erosion ranging from 80 to $220 \mathrm{~km}^{3} / \mathrm{km} / \mathrm{Myr}$ along the trench (Bourgois et al., 1990). As pointed out by Lallemand et al. (1992), the lower plate must be considered to have an elastic behaviour, leading to constant accommodation of erosion by progressive uplift. The computed subsidence for the last 20 Myr yields subductionerosion rates varying from 60 to $85 \mathrm{~km}^{3} / \mathrm{km} / \mathrm{Myr}$ along the trench when taking into account such a behaviour. Each method of calculation gives roughly concordant subduction-erosion rates. Along the Chiclayo canyon, the estimated amount of solid material removed by subduction-erosion varies from 128 to $526 \mathrm{~km}^{3} / \mathrm{km}$ along the trench, which yields subduction-erosion rates from 25 to $103 \mathrm{~km}^{3} / \mathrm{km} / \mathrm{Myr}$ along the trench, respectively (Sosson et al., 1994).

\section{Dip change of the slab}

The subsidence of the Peruvian margin during the last 20 Myr may also be explained by changes in the configuration of the subduction zone, related to a progressive increase of the subduction plane dip induced by a westward retreat of the slab (Sébrier and Soler, 1991). Mercier et al. (1992) suggested that weakening of the crust occurred for successive periods, probably extensional, during which the slab progressively lengthened and increased in depth, therefore favouring a seaward migration of the slab flexure. Thickening of the crust occurred during the compressional events (Sébrier and Soler, 1991), resulting from the rupture of a long, high-angle dipping slab under its own weight (Mercier et al., 1992).

\subsection{Shallow seismicity}

From 1970 to 1992,17 shallow earthquakes occurring along the northern Peruvian margin have been recorded by the world seismic network (Dziewonsky et al., 1981-1992; USGS-NEIC,
1988). Most of the hypocenters are located between $3^{\circ} \mathrm{S}$ and $7^{\circ} \mathrm{S}$ and $82^{\circ} \mathrm{W}$ to $80^{\circ} \mathrm{W}$, at depths varying from 15 to $62 \mathrm{~km}$ and with magnitudes between 5.1 and 7.4.

The epicenters are located in the trench, along the continental slope and up to $80 \mathrm{~km}$ landward from the coast, around the southernmost part of the Dolores-Guayaquil fault system (Fig. 2). Shepherd and Moberly $(1975,1981)$ assumed that this fault system is a major tectonic limit and that the region encompassing coastal Ecuador and Colombia could be regarded as a separate miniplate. As noted by Boinet et al. (1985), the coastal part of Ecuador and Columbia forms the southern prolongation of the Caribbean plate and the Dolores-Guayaquil megashear delineates its

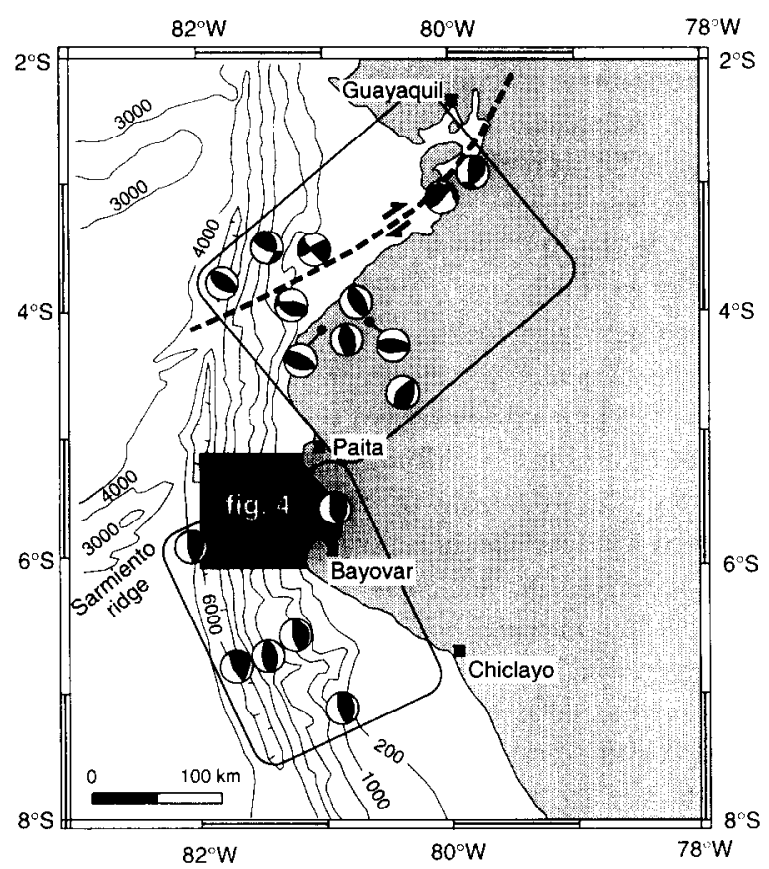

Fig. 2. Location of focal mechanisms for earthquakes recorded by the world seismic network, from 1981 to 1992, at a depth below $60 \mathrm{~km}$, along the northern Peruvian margin, between $2^{\circ}$ and $8^{\circ} \mathrm{S}$. The fault-plane solutions were determined by Harvard Centroïd-Moment-Tensor solutions (CMT) (Dziewonsky et al., 1981-1992) or derived from the first motion (USGS catalogs 1977-1992). The two rectangles delineate two major sets of earthquakes. The dashed line indicates the presumed seaward continuation of the Dolores-Guayaquil fault system, as assumed by Shepherd and Moberly (1975, 1981). Black area: location of the surveyed area offshore Paita. 
southeastern boundary. The shallow seismicity includes focal mechanisms indicating both thrusts faulting occurring along the subduction contact and dextral strike-slip motion along the southsouthwestern trend of the Dolores-Guayaquil fault system. Along the Andean-plate boundary, Dewey and Lamb (1992) have defined four neotectonic segments where the distribution of the deformation is partitioned in strain. The Paita area is located at the boundary of two segments. They extend in the north between $5^{\circ} \mathrm{N}$ and $6^{\circ} \mathrm{S}$ and in the south between $6^{\circ} \mathrm{S}$ and $20^{\circ} \mathrm{S}$. The shallow seismicity recorded between $6^{\circ} \mathrm{S}$ and $2^{\circ} \mathrm{S}$ seems to be related to the northern segment behaviour as defined by Dewey and Lamb (1992), where the plate slip vector is split into an orthogonal Benioff zone slip along the trench and a dextral-slip faulting along the Dolores-Guayaquil fault system.

Seismological studies reveal also a well-defined segmentation of the Benioff-Wadati zone below South America. In northern and central Peru $\left(2^{\circ} \mathrm{S}-15^{\circ} \mathrm{S}\right)$ and in central Chili $\left(27^{\circ} \mathrm{S}-33^{\circ} \mathrm{S}\right)$, the slab is marked by a dip of $5^{\circ}-10^{\circ}$, whereas the other segments show a dip of about $25^{\circ}-30^{\circ}$ (Isacks and Molnar, 1971; Stauder, 1973, 1975; Barazangui and Isacks, 1976). The vertical cross section of shallow seismicity drawn around $5^{\circ} \mathrm{S}$ shows the first kilometers of the Benioff zone along the margin (Fig. 3). Along this seismological depth section, the location of the CDP3 line seismic reflections have been reported at the same scale. The oceanic crust is clearly imaged from the trench to $10 \mathrm{~km}$ landward with a mean dip of about $3^{\circ}$, along the CDP3 line. It might be concluded that the scismic activity recorded along the first hundred kilometers of the subduction zone occurs within the lower plate. The compressive state of stress thus characterizes the deformation of the subducting Nazca plate. The normal faulting and sliding processes which occur along the continental slope of the continental margin appear therefore as more superficial events.

\section{Bathymetry of the continental slope}

The margin consists of three major domains, including from the continent to the trench: a flat

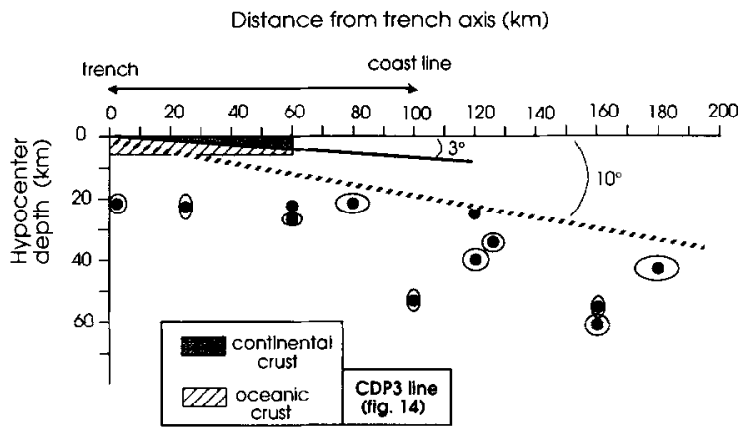

Fig. 3. Cross-section of the earthquakes shown on Fig. 2. All hypocenters determined by CMT solutions are reported. Some of hypocenters determined by first motions have been deleted due to the inaccuracy of solutions in depth. The earthquakes are plotted on the same scale as the CDP3 profile. The grey and dashed areas represent the location of CDP3 line reflections along this depth section. The depth of the oceanic crust was deduced from the depth section of the CDP3 line. Ovals around points illustrate the uncertainty of location.

continental shelf, a steep continental slope and a flat and narrow Peruvian trench (Fig. 1).

From east to west, the continental slope has been divided into three distinct sub-domains (Figs. 4 and 5): (1) the upper slope, with a continuous slope gradient of about $5^{\circ}$ in its central and southern part; (2) the middle slope, with slope gradients varying from $4^{\circ}$ to $30^{\circ}$; its central part displaying a well developed set of seaward curved features; and ( 3 ) the lower slope, characterized by the occurrence of both trench-parallel ridges at the trench boundary in the northern part of the surveyed area and a zone of hummocky topography at the base of the curved features of the middle slope.

The seaward curved scarps are named, from upslope to the trench: the upper slope scarp (USS), the middle slope scarp (MSS) and the lower slope scarp (LSS) (Lagabrielle et al., 1992). The westernmost scarp (trench scarp: TS), however, shows a linear trend. This scarp was named subduction scarp (SS) by Dia et al. (1993), and marks the boundary between the Nazca and the South American plates (Figs. 4 and 5).

\subsection{The upper slope}

The upper slope extends between 200 and 3000 $\mathrm{m}$ of water. It is incised up to $400 \mathrm{~m}$ deep, by five 


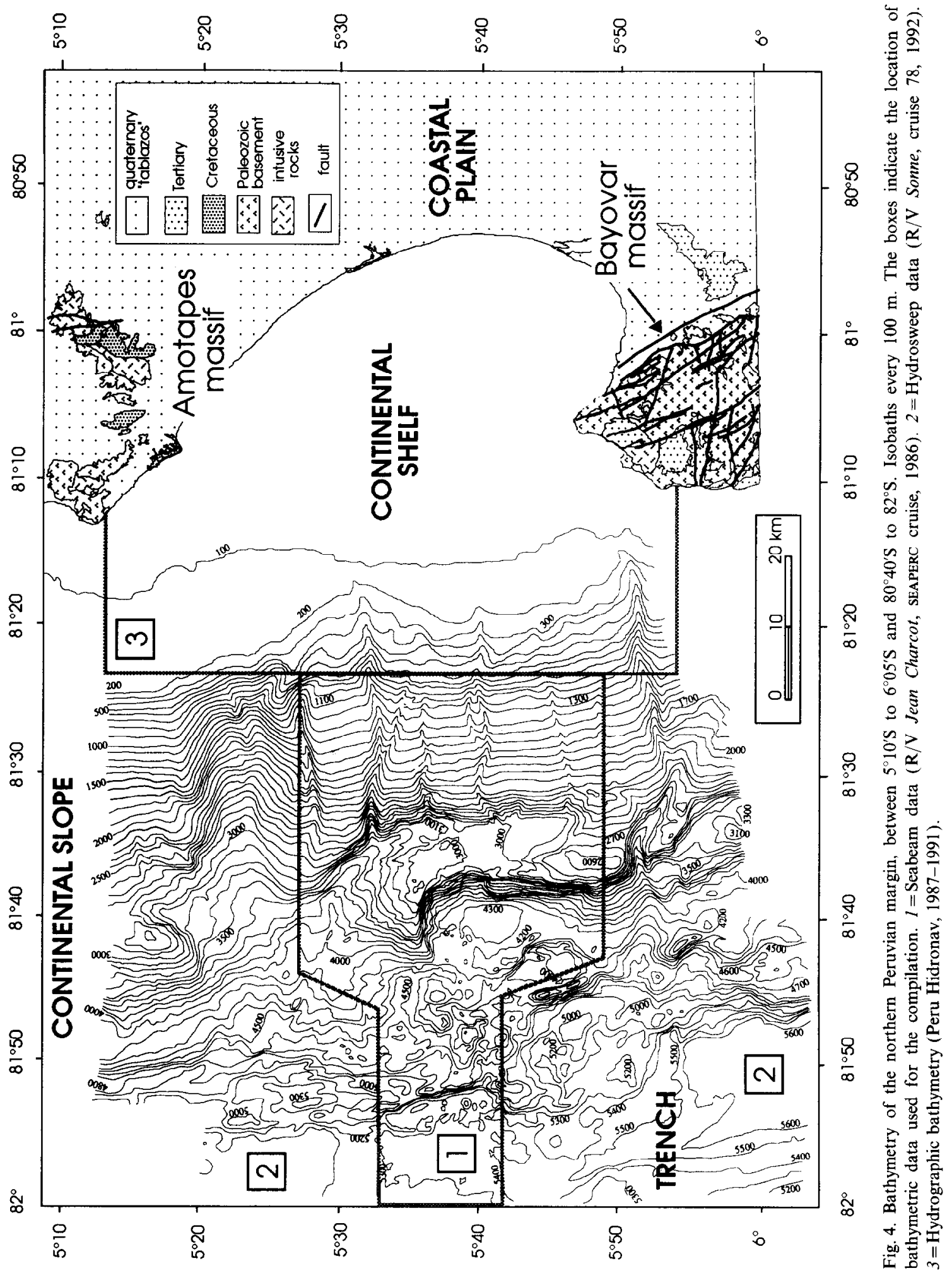




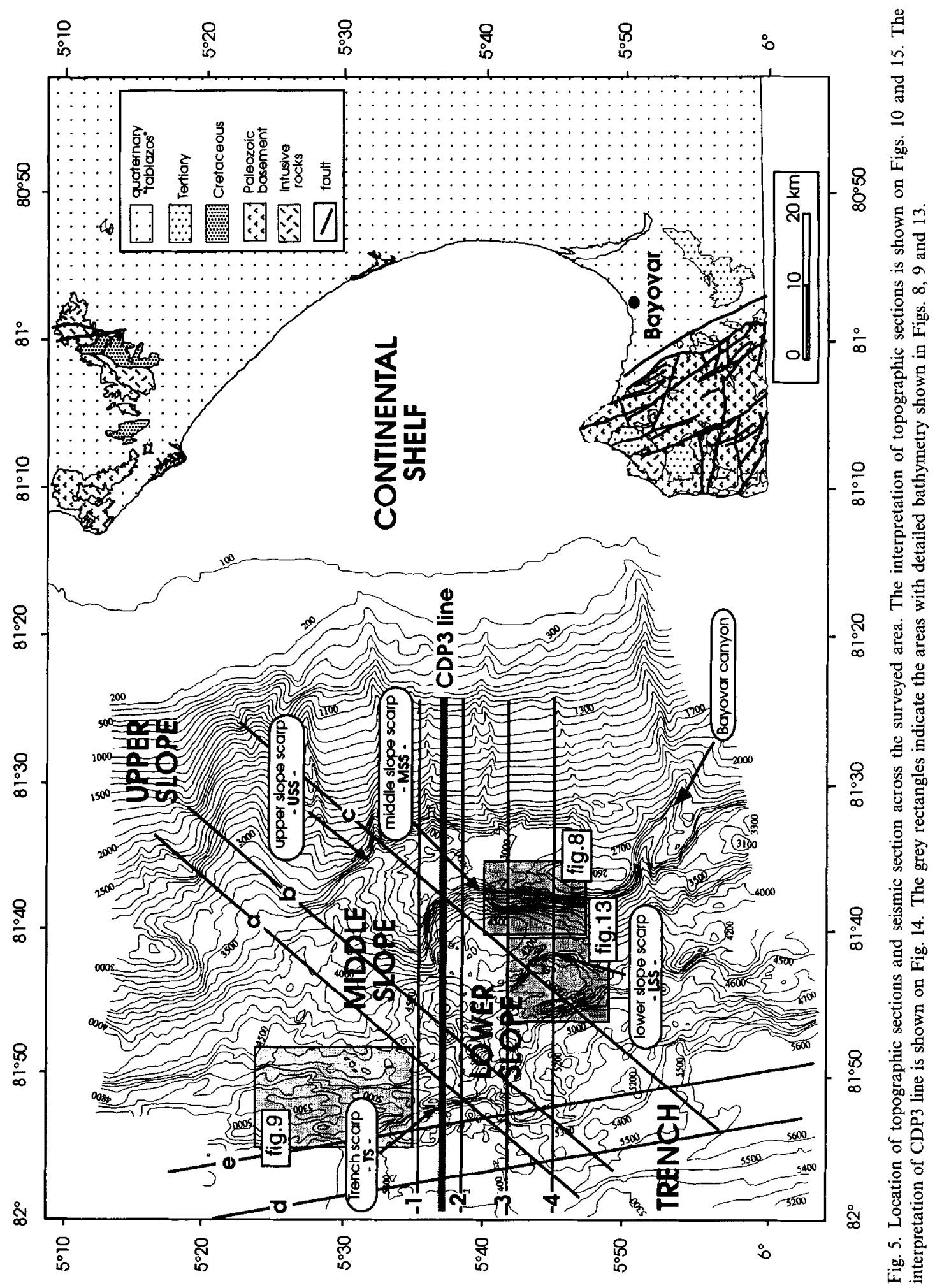


parallel V-shaped canyons, trending $\mathrm{E}-\mathrm{W}$ along the line of maximum slope (Bourgois et al., 1988; Von Huene et al., 1989). A large part of the northern Peruvian coastal plain consists of Pleistocene uplifted marine terraces, locally known as "tablazos" (De Vries, 1988), which provide a good record of the major vertical motions that occurred along the coastal area of northern Peru during late Quaternary times (Macharé and Ortlieb, 1993). However, the origin of the continental slope canyons cannot be explain by these recent coastal uplifts, because no large river exists onshore along the coastal plain and the continental shelf bathymetry does not display any canyon features (Figs. 4 and 5). The canyons are therefore supposed to have been formed during sea-level variations related to vertical motions older than the Quaternary.

\section{The upper slope scarp (USS)}

The USS is a curved scarp extending some $30 \mathrm{~km}$ along the limit between the upper slope and the middle slope area. It has a slope gradient of $25^{\circ}$ and varies in height from $100 \mathrm{~m}$ in the south to $500 \mathrm{~m}$ in the north (Figs. 5 and 6). The base of the scarp is marked by a north-northwestern oriented seaward curved valley. Four canyons, which run downslope along the upper slope, cut through the USS and flow into this curved valley. They connect to the curved valley and do not cut through the middle slope. Southward, offshore Bayovar, the USS and its basal valley disappear. Here, the southernmost canyon (Bayovar canyon) cuts through the entire slope and reaches the trench with an almost continuous direction.

During the NAUTIPERC cruise three dives were conducted along the USS at the intersection with two canyons of the upper slope (Fig. 7). In situ structural observation of the scarp was not possible due to a thick cover of Quaternary pelagic ooze, but the whole scarp displays a smooth and regular morphology. The basal part of the surveyed canyons is also covered by a thick layer of pelagic sediments. Nevertheless, the discovery of three dense communities of living clams related to fluids vents indicates fluid circulation along these canyons.

\subsection{The middle slope}

The middle slope extends from 3000 to $4500 \mathrm{~m}$ water depth. Between $5^{\circ} 40^{\prime} \mathrm{S}$ and $5^{\circ} 30^{\prime} \mathrm{S}$, it shows a dome-shaped surface and a structural pattern roughly parallel to the curvature of USS (Fig. 5). This surficial structural pattern consists of numerous arcuate ridges and valleys of about $3 \mathrm{~km}$ long, including a large and curved valley which progressively opens up along the base of the USS (Fig. 6). The ridges and valleys can be considered as opening fissures and their occurrence suggests that the structural fabric of the area is controlled by mass movements in relation to slope instabilities (Lagabrielle et al., 1992; Duperret et al., 1993). As assumed by Bourgois et al. (1993), the domeshaped deformation of the middle slope area indicates a broad rollover fold formed in association with a major seaward-dipping detachment fault along the USS.

\section{The middle slope scarp (MSS)}

The MSS forms the main feature of the middle slope. It extends over $25 \mathrm{~km}$ and shows an average slope gradient varying from $10^{\circ}$ to $30^{\circ}$ over a total denivellation of $1 \mathrm{~km}$. The MSS has a curved shape, its northern and southern parts trending $\mathrm{E}-\mathrm{W}$ and $\mathrm{N}-\mathrm{S}$, respectively. It exhibits a typical shape of debris-slide breakaway (Bourgois et al., 1986, 1988, 1993; Von Huene et al., 1989). A detached block (MSS'), with a length of $13 \mathrm{~km}$ and $1 \mathrm{~km}$ wide is located south of $5^{\circ} 40^{\prime} \mathrm{S}$ (Fig. 8). It shows a convex slope profile in the north and is still connected to the scarp by its southern part. The block is limited upslope by a N-S trending elevated valley, which connects to a curved canyon cutting the MSS. The morphology of the scarp shows the MSS' as a toppling block located along a scarp with high slope gradients. The elevated valley upslope could thus be considered as a fissure track along which the MSS' $^{\prime}$ is gliding.

In situ structural description of MSS Eight deepsea dives of the submersible Nautile were conducted along the MSS (Fig. 7). They show the scarp to be composed of a succession of small cliffs (of an average $10 \mathrm{~m}$ height) exposing barerock outcrops with fresh screes and alternating 


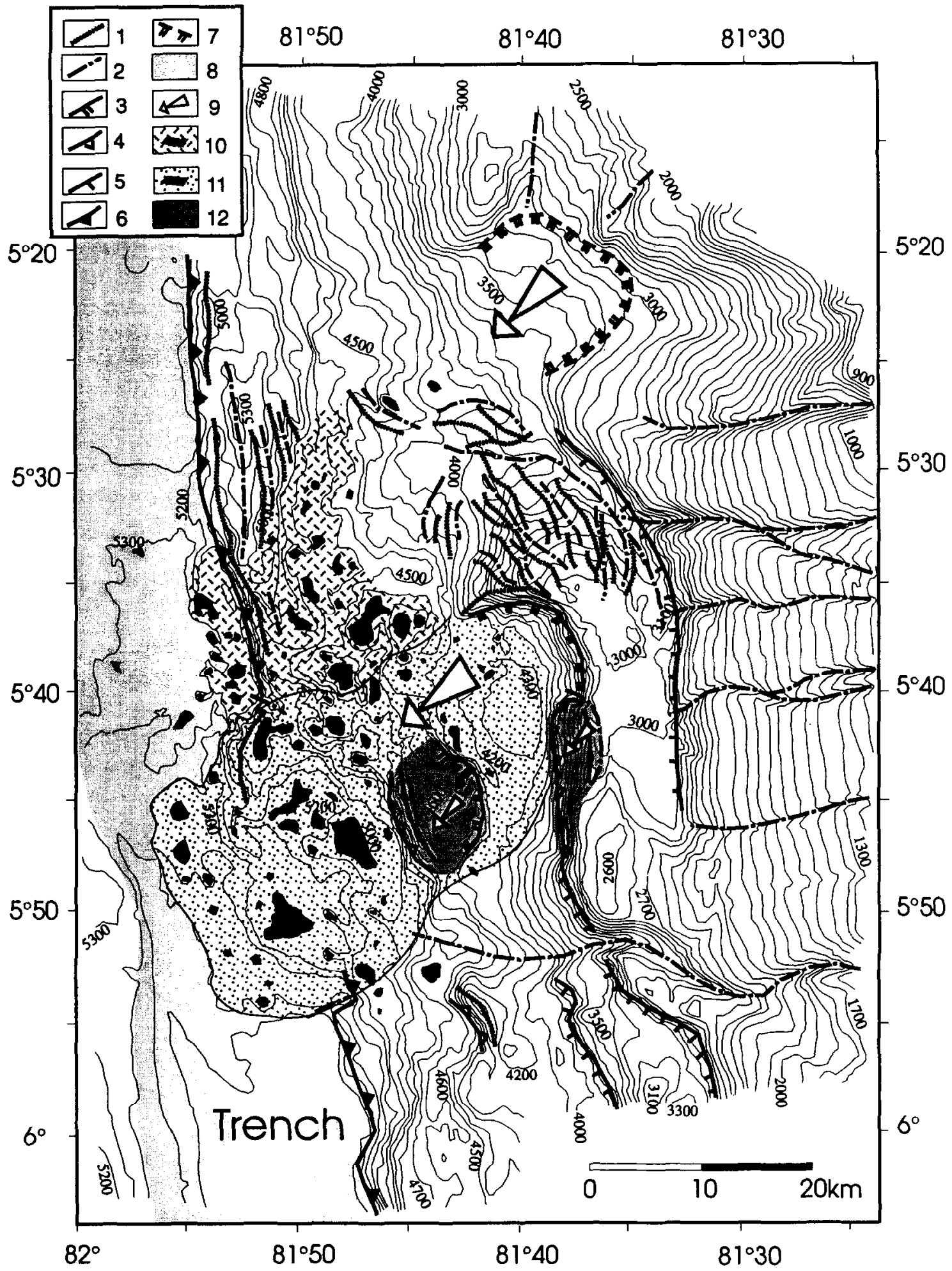

Fig. 6. Structural interpretation as deduced from the bathymetry. $1=$ Ridge axis; $2=$ valley axis; $3=$ sliding scar; $4=$ gliding block; $5=$ normal fault; $6=$ subduction contact; $7=$ supposed location of sliding scar; $8=$ trench sea-floor; $9=$ direction of sliding for each phase of slope failure; $10=$ debris-avalanche of the phase 1 of slope failure (unit 1); $11=$ debris-avalanche deposit of the phase 2 of slope failure (unit 2); and 12 =gliding blocks of the phase 3 of slope failure. 


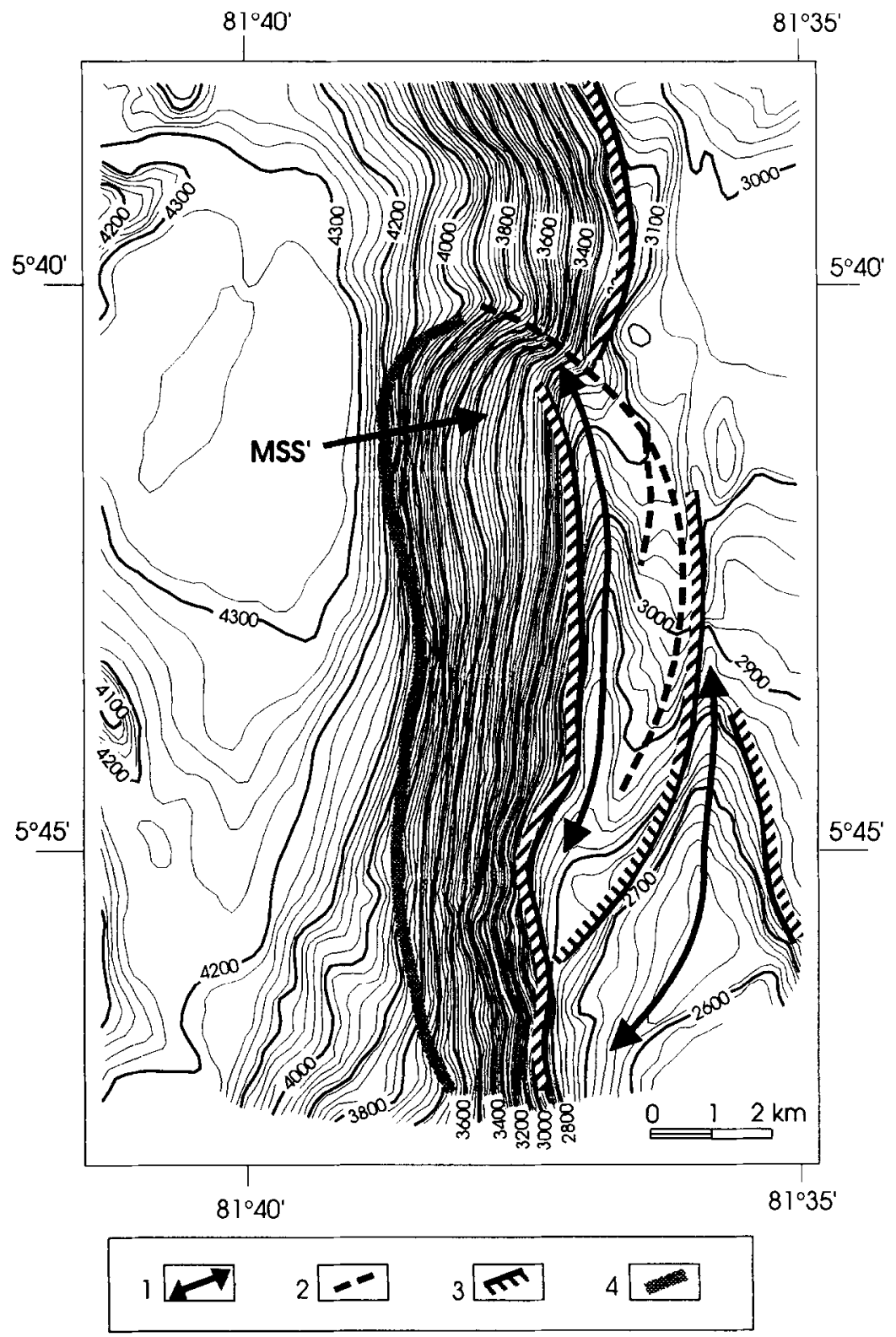

Fig. 7. Detailed bathymetry of the southern part of the MSS, along the middle slope. Isobaths every $20 \mathrm{~m}$. For location: see Fig. 5. The MSS displays another detached block, named $M S S^{\prime}$. $1=$ Ridge axis; $2=$ valley axis; $3=$ scarp; and $4=$ basal limit of the detached block $\left(M S S^{\prime}\right)$, defined both by the change of concavity and by the change of slope gradient along the MSS.

with flat steps covered with recent pelagic ooze. A dense net of joints and fractures of various size (decimeter, meter scale) can be observed along the scarp. Some scars occur locally, indicating that rock falls and others gravity processes are still active along the scarp. In situ observations indicate that the MSS is the scar of a rock-fall or a debris avalanche. The freshness of the scar allows us to assume that the slope failure occurred recently. 


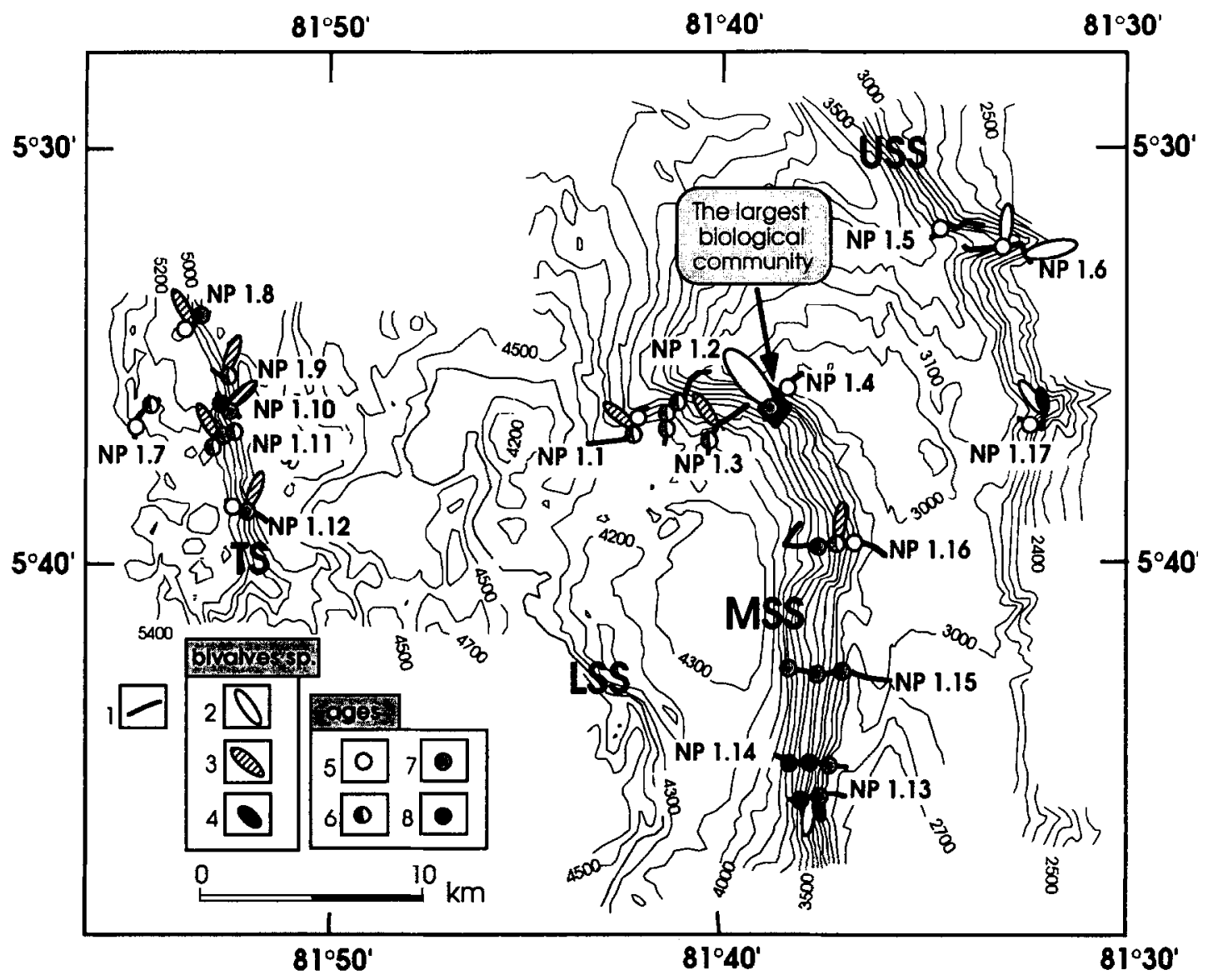

Fig. 8. Biological communities and age of rocks samples collected by the submersible Nautile surveys during the NAUTIPERC cruise, in 1991. $I=$ Location of dive tracks. Ovals indicate the location of biological communities related to cold seeps. The size of each oval is indicative of the size of the community. 2 =Communities of Calyptogena sp. 1, composed of numerous round-shaped clams. $3=$ Communities of Calyptogena sp. 2, composed of few elongate-shaped clams. 4=Communities of Vesicomya sp. The largest biological community is composed of numerous Calytogena sp. 1, large thickets of Serpulidae, bacterial mats and barite deposits (from Olu et al., 1994a,b). Circles indicate the age of rock samples. 5=Quaternary. $6=$ Plio-Quaternary. $7=$ Pliocene. 8=Miocene (from De Wever et al., 1995).

Dating of rock samples Micropaleontological results obtained from the samples collected along the different sections, allow us to reconstruct a stratigraphic sequence of the middle slope area (Fig. 7) (De Wever et al., 1995). The southernmost part of MSS exhibits mudstones and sandstones of late Miocene age to Pliocene and PlioQuaternary age. By contrast, the northern part of the MSS exposes sediments of Plio-Quaternary and Quaternary age only. This suggests that the sequences are tilted towards the north (Duperret et al., 1993; Bourgois et al., 1993). This northward plunge may be related to the occurrence of a rollover fold along the detachment fault emerging upslope at USS (Bourgois et al., 1993) (Fig. 12).

Cold seeps along MSS Biological communities composed of live communities of clams, tube worms and small patches of bacterial mats were discovered at different stations along the surveyed features of the slope (Fig. 7). The presence of chemoautotrophic benthic biological communities is commonly interpreted as a tracer of active fluid flow out of the seabed (Suess et al., 1985; Le Pichon et al., 1987; Boulègue et al., 1987; Moore 
and Vrolijk, 1992). Since the first in situ observation of biological communities related to cold seeps on the Oregon accretionary margin (Suess et al., 1985), similar observations have been reported from active erosional margins (Cadet et al., 1987; Sibuet et al., 1988) as well as from active accretionary margins (Le Pichon et al., 1987, 1990). Two main types of communities have been defined on the basis of the size and density of the bivalves (Olu et al., 1994a). Calyptogena sp. 2 communities are composed of less than 20 individuals. They have been recognized along the MSS and along the trench scarp (TS) (Fig. 7). Calyptogena sp. 1 communities are composed of larger and denser beds of 50 to 100 individuals. They have been recognized along the canyons of the upper slope and at the bend of MSS, where they compose the largest and most dense vent site ever observed at an active margin. This gigantic vent site is located at the intersection of $\mathrm{N}-\mathrm{S}$ trending part of the MSS and the E-W canyons of the upper slope (Fig. 7) and displays clams associated with exceptionally well-developed thickets of tube worms (Serpulidae), bacterial mats and barite concretions. Somewhere, few individuals of Vesicomya sp. are associated with the two species of Calyptogena (Olu et al., 1994a,b). Geochemical analysis of the fluids inside these barite concretions suggest an interaction with the Paleozoic basement (Dia et al., 1993). On several locations of the margin, the Paleozoic outcrops reveal E-W and N-S trending fault system: Along the Bayovar and Amotapes massifs on the coastal plain, onshore Paita and along the Chiclayo canyon (Sosson et al., 1994), to the south, offshore Paita (Fig. 4). Offshore Paita, the canyons of the upper slope and their connection to the middle slope via the deep detachment fault merging at the USS also form an E-W/N-S fault system. All these observations seem to indicate a fluid flow across the northern Peruvian margin, from upslope to downslope, channeled through an inherited $\mathrm{E}-\mathrm{W} / \mathrm{N}-\mathrm{S}$ trending fault system, along the line of maximum slope.

\subsection{The lower slope}

The lower slope extends from $4500 \mathrm{~m}$ to 5300 $\mathrm{m}$ (Figs. 5 and 6 ). Its main feature is a wide masswasting deposit located in the central part of the studied area. On both sides of the deposit (i.e. to the north and to the south), the lower slope displays different morphotectonic and trending features.

\section{The northern part of the lower slope}

The northern part of the slope is marked by a system of parallel $\mathrm{N}-\mathrm{S}$ trending ridges and valleys. They extend northward from the mass-wasting deposit, from the trench up to $9 \mathrm{~km}$ upslope (Fig. 9). The ridges have a variable length and a

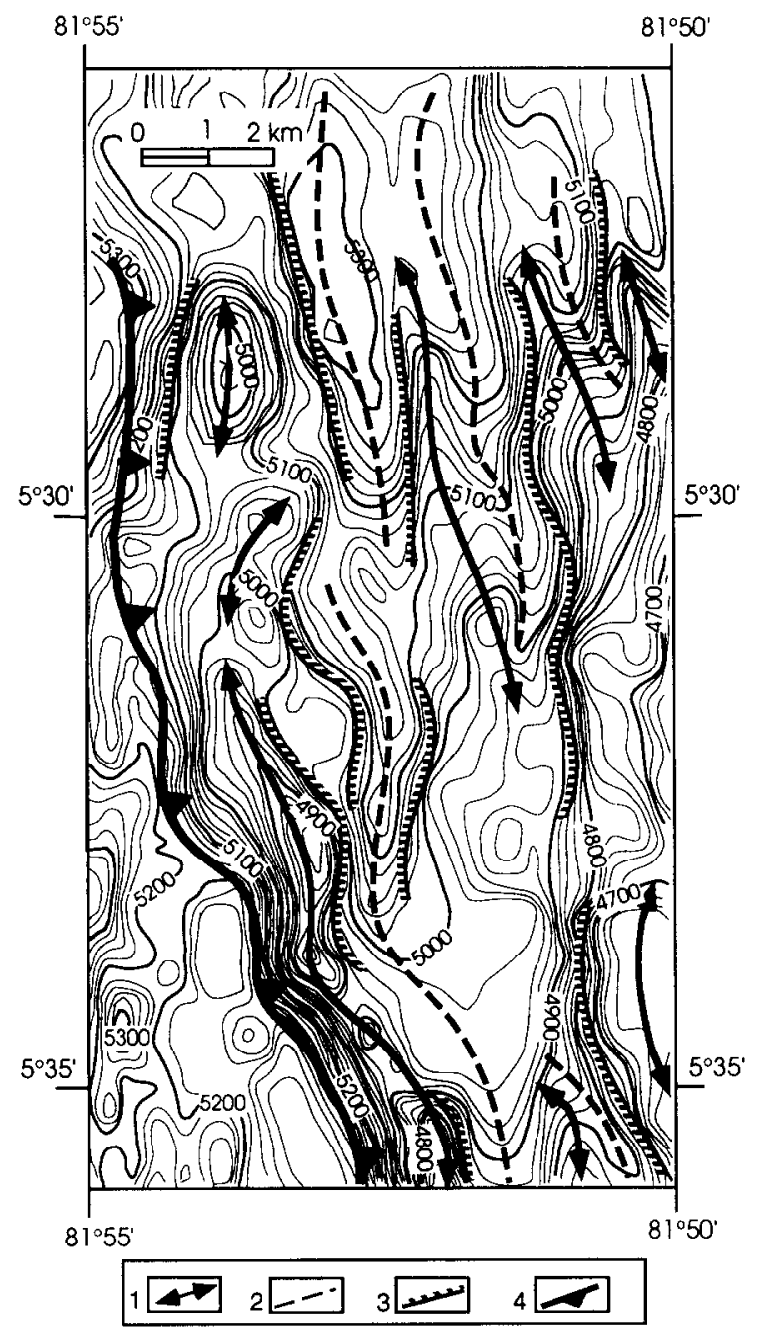

Fig. 9. Detailed bathymetry of the lower slope along its northern part. Isobaths every $20 \mathrm{~m}$. For location: see Fig. 5. At this location, the lower slope displays a roughly $\mathrm{N}-\mathrm{S}$ trend of ridges and valleys. $1=$ Ridge axis; $2=$ valley axis; $3=$ scarps; and $4=$ subduction contact. 
width from 1 to $2 \mathrm{~km}$. They are thought to be the expression of reverse faulting that could be related to compression along the lower slope. It is therefore likely that a small accretionary wedge exists along the northern part of the studied area. South of $5^{\circ} 30^{\prime} \mathrm{S}$ the contact between the lower slope and the trench is marked by a rectilinear scarp trending $\mathrm{N} 170^{\circ}$ : the so-called trench scarp (TS). At this location, the orientation of the plate contact changes from $\mathrm{N} 180^{\circ}$ to $\mathrm{N} 170^{\circ}$.

\section{The southern part of the lower slope}

The southern part of the slope exhibits a general $\mathrm{N} 170^{\circ}$ trend and expands from the trench up to $3000 \mathrm{~m}$ of water depth on the slope (Fig. 6). Two parallel linear seaward scarps trending $\mathrm{N} 170^{\circ}$ are located upslope, along the middle slope. They do not present an arcuate shape and do not seem to be scars left by slides. They may correspond to the emergence of normal faults, parallel to the $\mathrm{N} 170^{\circ}$ trending subduction contact and developed on the slope along the southward continuation of the MSS. Along this part of the slope, no sliding features nor compressional features have been recognized.

\section{The mass-wasting deposits}

Between $5^{\circ} 40^{\prime} \mathrm{S}$ and $5^{\circ} 55^{\prime} \mathrm{S}$, the subduction contact is completely buried under a disorganized mass of sedimentary rocks (the blocks size varies from 1 to $5 \mathrm{~km}$, with an average height of 100-200 m) (Fig. 6). This topography was interpreted as the result of a chaotic debris slide deposit, which covers the middle part of the lower slope and infills the trench over a distance of some $10 \mathrm{~km}$. The deposit consists of roughly equi-dimensional closed contours hills and depressions without any specific trends (Bourgois et al., 1986, 1988).

From a network of topographic sections two morphological units of mass-wasting deposits have been defined along the slope (Fig. 5). Fig. 10 shows two parallel topographic sections oriented $\mathrm{N} 170^{\circ}$. The westward section (d) displays the flat sea-floor of the trench slightly perturbated by the chaotic topography of the distal part of a deposit (unit 2). The eastward section (e) shows two sorts of deposit (unit 1 and 2). The first one is located at the base of the trench scarp (TS), between $5^{\circ} 35^{\prime} \mathrm{S}$ and $5^{\circ} 40^{\prime} \mathrm{S}$ and displays a chaotic topography. The second deposit is found between $5^{\circ} 40^{\prime} \mathrm{S}$ and $5^{\circ} 55^{\prime} \mathrm{S}$, at the base of the buried subduction contact. It shows a sharp rise and reaches a mean thickness of about $500 \mathrm{~m}$. Additional parallel topographic sections have been drawn in the central part of the margin along a $\mathrm{N} 230^{\circ}$ axis (Fig. 11). The northern section (a) displays a deposit which extends over a distance of $5 \mathrm{~km}$ in the trench (unit 1). The deposit has partially buried the $\mathrm{N} 170^{\circ}$ trending ridge at the edge of the lower slope and is cut by the TS. The middle section (b) reveals a deposit
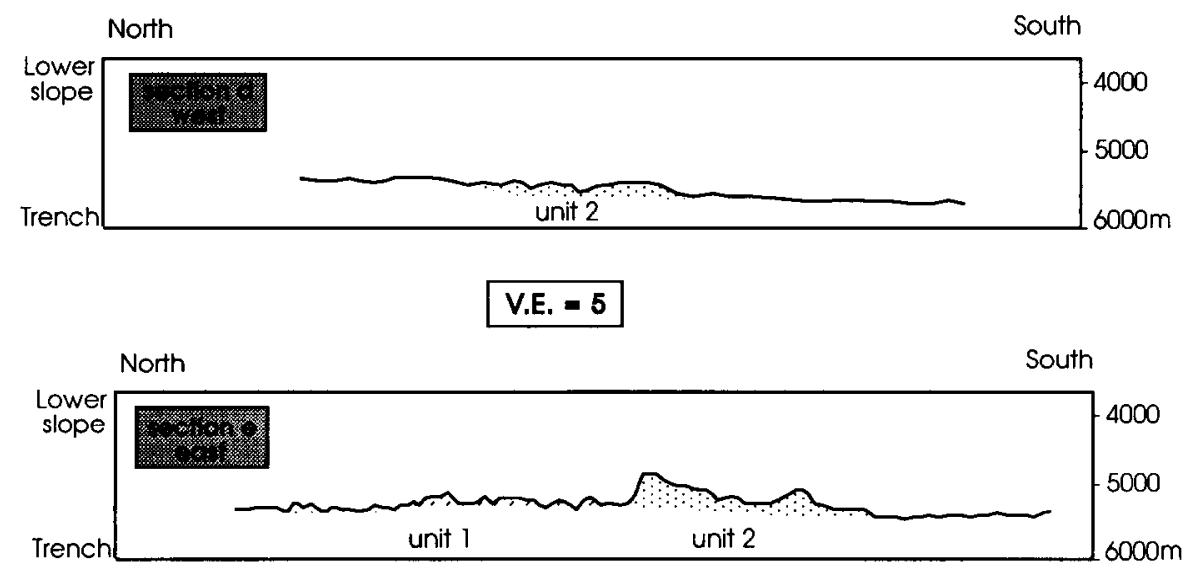

Fig. 10. $\mathrm{N} 170^{\circ}$ topographic sections conducted along the trench axis, from the trench to the lower slope. The westward section (d) evidences the distal part of the second debris-avalanche (unit 2), which extends up to $10 \mathrm{~km}$ on the trench. The eastward section (e)evidences the first deposit in the north (unit 1) and the second deposit in the south (unit 2). 

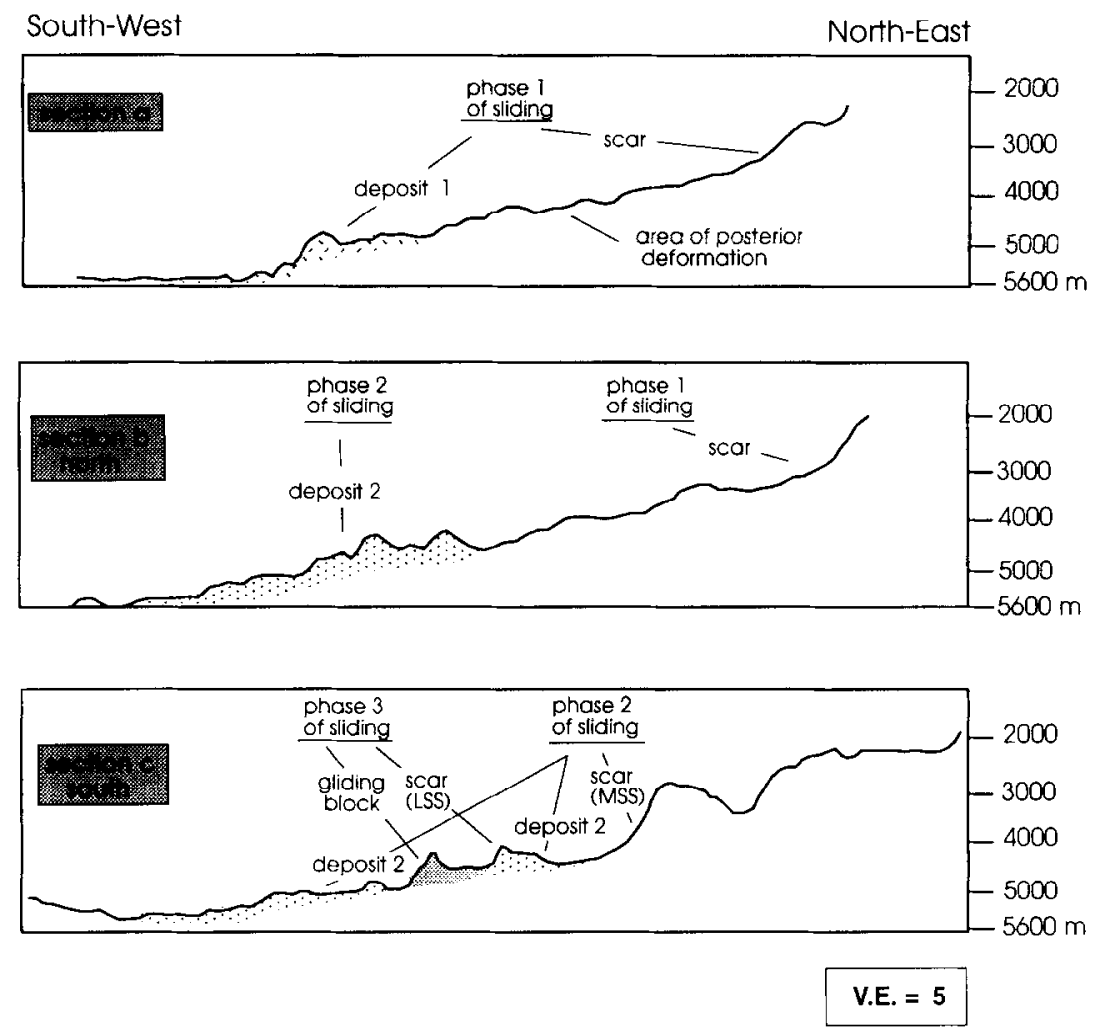

Fig. 11. Superposition of parallel NE-SW topographic scetions on the slope. For location: see Fig. 5. Section (a) cuts the first sliding of the slope and shows unit 1 of the debris-avalanche, on the lower slope and on the landward part of the trench. Sections (b) and (c) cut through the second sliding of the slope and show unit 2 of the debris-avalanche. Section (c) also shows the third phase of slope failure (gliding block along the LSS).

(unit 2) which extends both along the lower slope and along the trench over a distance of $10 \mathrm{~km}$ and which completely buries the TS.

Deposit 1: the first phase of slope failure Unit 1 is located in the north and extends over a distance of about $5 \mathrm{~km}$ along the trench. The deposit is assumed to be an old mass-wasting deposit, as it is cut by the TS. This deposit is bounded westward by the $\mathrm{N}-\mathrm{S}$ folding developed to the north of the lower slope (Fig. 9) and eastward by the rollover fold located along the middle slope (Fig. 6). No tracks of sliding have been evidenced along the seaward flank of the rollover fold, the sliding probably occurred prior to the anticline deformation of the middle slope. Furthermore, as folds seems to be partly buried by the deposit, the sliding takes place after $\mathrm{N}-\mathrm{S}$ folding, but prior to the formation of the TS (Fig. 12). This indicates that the compressive deformation of the lower slope has occurred prior to the rollover fold which extends along the middle slope. The $\mathrm{N}-\mathrm{S}$ ridges and vallcys could represent an incipient accretionary prism. This folding therefore appears as an old deformation of the slope and evidences a compressive tectonic regime inferred by the north Peruvian margin prior to the present-day extensive one. Deposit 1 may have originated from the large erosive valley with a smooth topography located on the northern part of the middle and upper slopes. This mean that sliding 1 occurred along a roughly $\mathrm{N} 230^{\circ}$ trend (Fig. 6 ).

Deposit 2: the second phase of slope failure Unit 2 is located southward of unit 1 and extends over a 


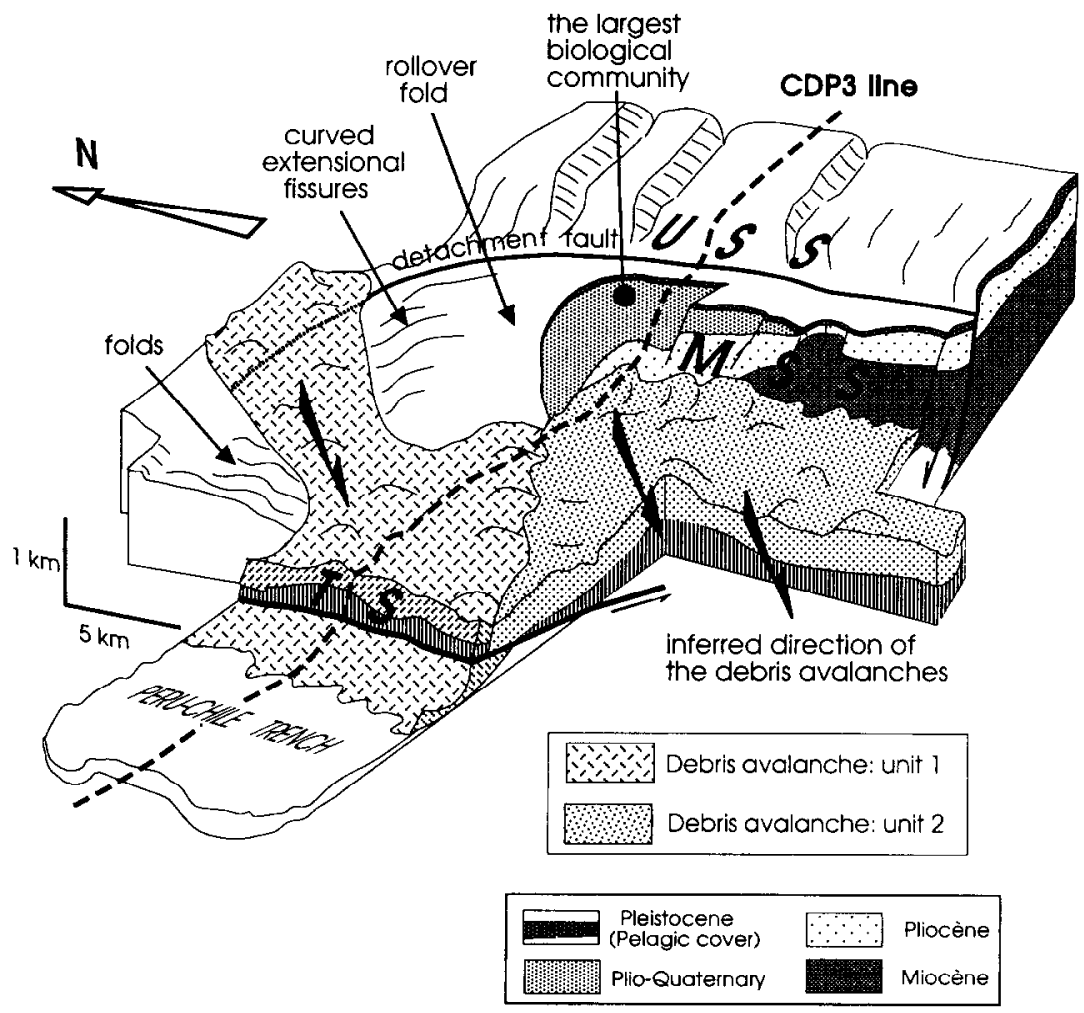

Fig. 12. Three-dimensional diagram showing the main geologic and tectonic features identified in the Paita area. USS=upper slope scarp; $M S S=$ middle slope scarp; and $T S=$ trench scarp. The CDP3 line is shown on Fig. 15.

distance of about $10 \mathrm{~km}$ along the trench. The deposit of unit 2 is assumed to have occurred later than unit 1 because it has completely buried the TS whereas unit 1 is cut by TS. We assume that unit 2 originated from the MSS which has been clearly documented as a fresh scar. The morphology of unit 2 and MSS indicates that the sliding 2 is a debris-avalanche, which has slid along a N230 trend during a second stage of failure along the slope (Fig. 12).

\section{The lower slope scarp (LSS)}

The lower slope scarp (LSS) is one of the main features of the lower slope. The scarp is crescentshaped and is $6 \mathrm{~km}$ long and $3 \mathrm{~km}$ wide. Detailed bathymetry of the scarp (Fig. 13), shows two ridges along the base of the LSS, at each bend of the crescent. The northern ridge is $2 \mathrm{~km}$ long, the southern $1 \mathrm{~km}$. They are connected to the LSS and are bordered by a parallel valley, developed between the ridges and the head of the LSS. The ridges may be considered as gliding blocks, detached from the head of the LSS by a rotation along the northern and southern bend of the crescent. Their detachment left two valleys along the central part of the scarp. The two detached blocks emphasize the shape of the LSS. Comparison between the isobaths of the blocks and the LSS indicates that the LSS was created before this detachment. The previous shape of the LSS was therefore more rectilinear, with a general $\mathrm{N} 160^{\circ}$ trend in the north and a $\mathrm{N} 230^{\circ}$ branch in the south.

An elongated block of $700 \mathrm{~m}$ height and $8 \mathrm{~km}$ long is located $4 \mathrm{~km}$ downslope from the LSS. It can also be considered as a gliding block. The elongated block glided down with a translational movement, thereby leaving on the lower slope a 


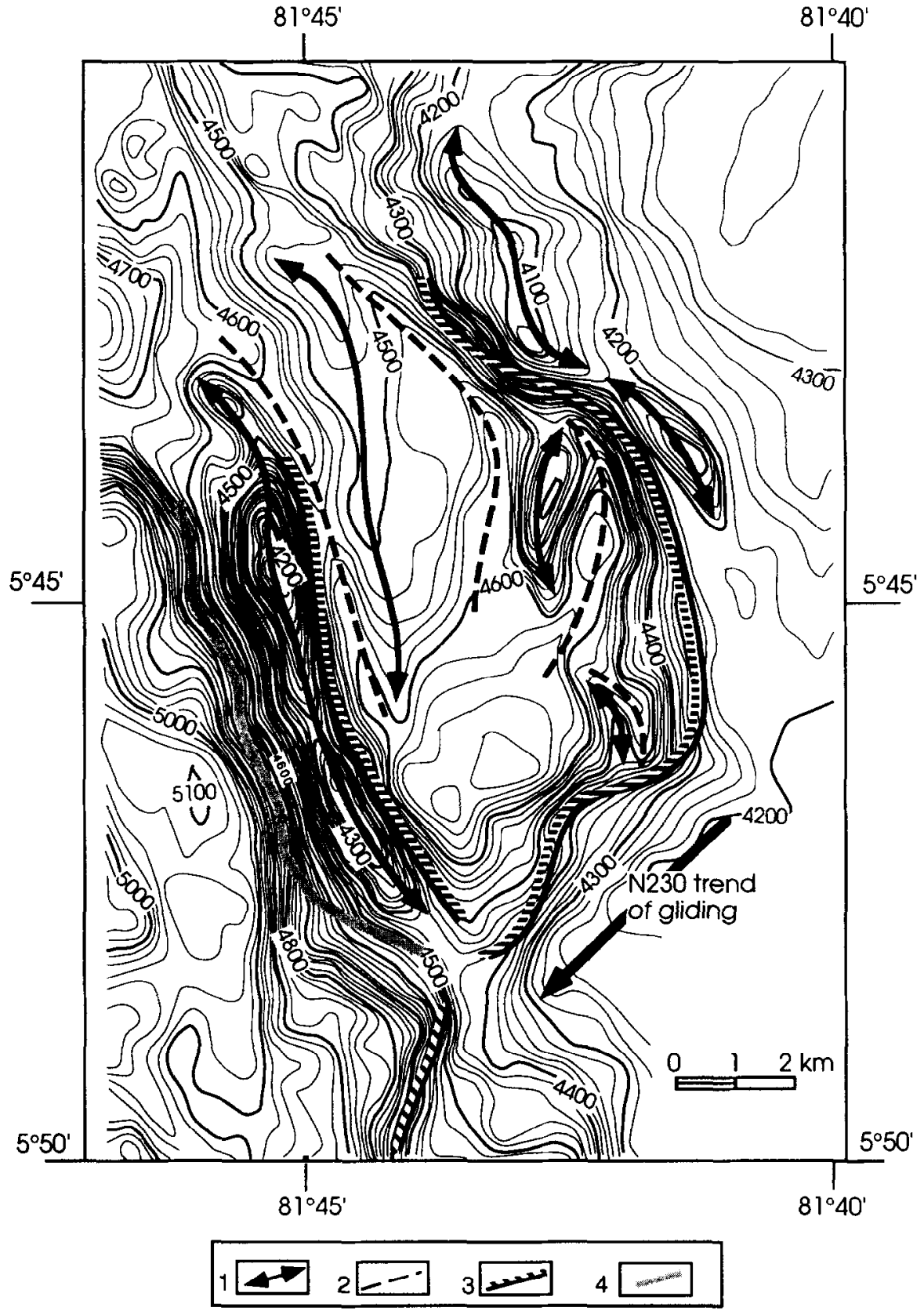

Fig. 13. Detailed bathymetry of the lower slope scarp (LSS) and its gliding block. Isobaths every $20 \mathrm{~m}$. For location: see Fig. 5 . The southern part of the LSS shows the $\mathrm{N} 230^{\circ}$ trending tracks of the gliding block. $I=$ Ridge axis; $2=$ valley axis; $3=$ scarp axis; and 4 =basal limit of the detached block.

$\mathrm{N} 160^{\circ}$ trending scar turning into a $\mathrm{N} 230^{\circ}$ trending track in the south. The flat area located between the LSS and the elongated block indicates the stiding plane. The slight landward bend of the elongated detached block is probably due to an increased gravitational stress on the middle part of the block.

As the instability occurs among the deposits left 
by the debris-avalanche during a previous phase of failure of the slope, the LSS documents a third stage of slope failure (Fig. 11).

\section{Model proposed for sliding reconstruction}

Detailed morphological analysis of the continental slope allows us to propose a new interpretation of the CDP3 line as described on Fig. 14. A series of E-W bathymetric sections drawn from north to south along the whole margin demonstrates the main morpho-tectonic features observed along the slope (Fig. 15). Three stages of slope failure can be defined along the margin, including three main slope-failure types and two different depositional units.

\subsection{First stage of slope failure}

The first phase of slope failure is evidenced by the subsequent deposit along the lower slope and the trench. This deposit was initially interpreted as the result of the slope failure occurring along the MSS (Bourgois et al., 1986, 1988, 1990, 1993; Von Huene et al., 1989; Duperret et al., 1993), due to a lack of bathymetric data to the north and to the south of the previous surveyed area. From the complementary data of the $\mathrm{R} / \mathrm{V}$ Sonne, this debris-avalanche is now assumed to originate from the northern wall of the wide valley located towards the north along the upper slope (Fig. 6). The resulting scar from which the deposit originated is not clearly defined due to its smooth topography as a result of its oldness. Therefore, the volume of rocks voided from the slope during this first stage of failure cannot easily be determined. Nevertheless, the similar morphology of units 1 and 2 allows us to assume that the older unit 1 also originated from a debris-avalanche. The distal part of unit 1 is now cut by the TS (Fig. 15, section 1) and offscrapped along it (Fig. 15, section 2).

\subsection{Second stage of slope failure}

The middle slope is deformed by a rollover fold along the detachment fault merging at the base of the USS (Fig. 14, section 1). This section is a reference-profile as it represents an uninterrupted phase of the slope, prior to the second stage of failure. The southern part of this rollover fold represents the second phase of slope failure, clearly documented by a debris-avalanche (Fig. 15). It is defined by a semi-crescent shaped head (MSS) and a hummocky depositional area of large broken blocks on the lower slope. The flat area located at the base of the MSS is partially in-filled by the debris-avalanche deposit and covers the basal part of the sliding plane (Fig. 15, section 2). The failure has therefore occurred along a rotational sliding plane, as can be seen on the CDP3 line (Fig. 14). As shown on Fig. 16, the volume of rocks voided by the debris-avalanche along the MSS can be determined by comparing the topographic profiles of the northern and southern part of the middle slope. It leads to a rough estimate of some $250 \mathrm{~km}^{3}$ of rocks. As indicated by the submersible observations, the freshness of the head scar suggests that the second debris-avalanche occurred more recently than the first one.

\subsection{Third stage of slope failure}

The third phase of slope failure is represented by two elongated blocks gliding along the LSS and the MSS. The block along the MSS (MSS') is defined by a change in the concavity of the scarp and by an upslope fissure track (Fig. 8). It delineates a vertical detachment surface along the MSS and appears thus as a toppled block (Fig. 15, section 3). A second gliding block is observed along unit 2 (Fig. 15, section 4). This block has glided down along a horizontal translational sliding plane over a distance of $4 \mathrm{~km}$ from the LSS and forms a translational slided block (Fig. 13). Both blocks display a similar gliding trend of $\mathrm{N} 230^{\circ}$. As sliding and toppling features are located on top of the features left by the second debrisavalanche, this third phase of slope failure is assumed to be younger than the two debrisavalanches, previously described.

\section{Factors responsible for submarine slope instabilities}

Classically, slope instabilities occur when the loads acting on sediment mass exceed the resistance 


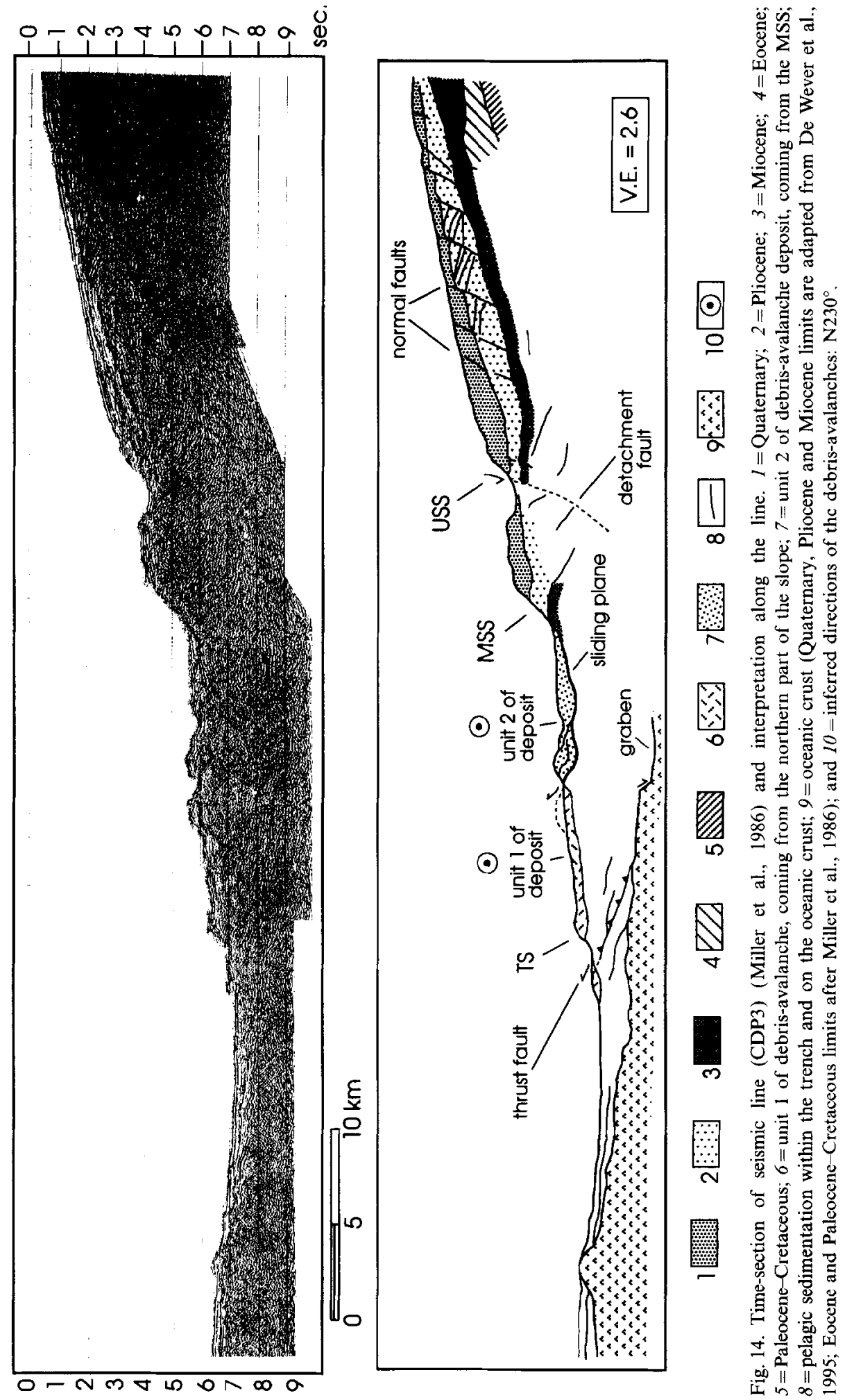



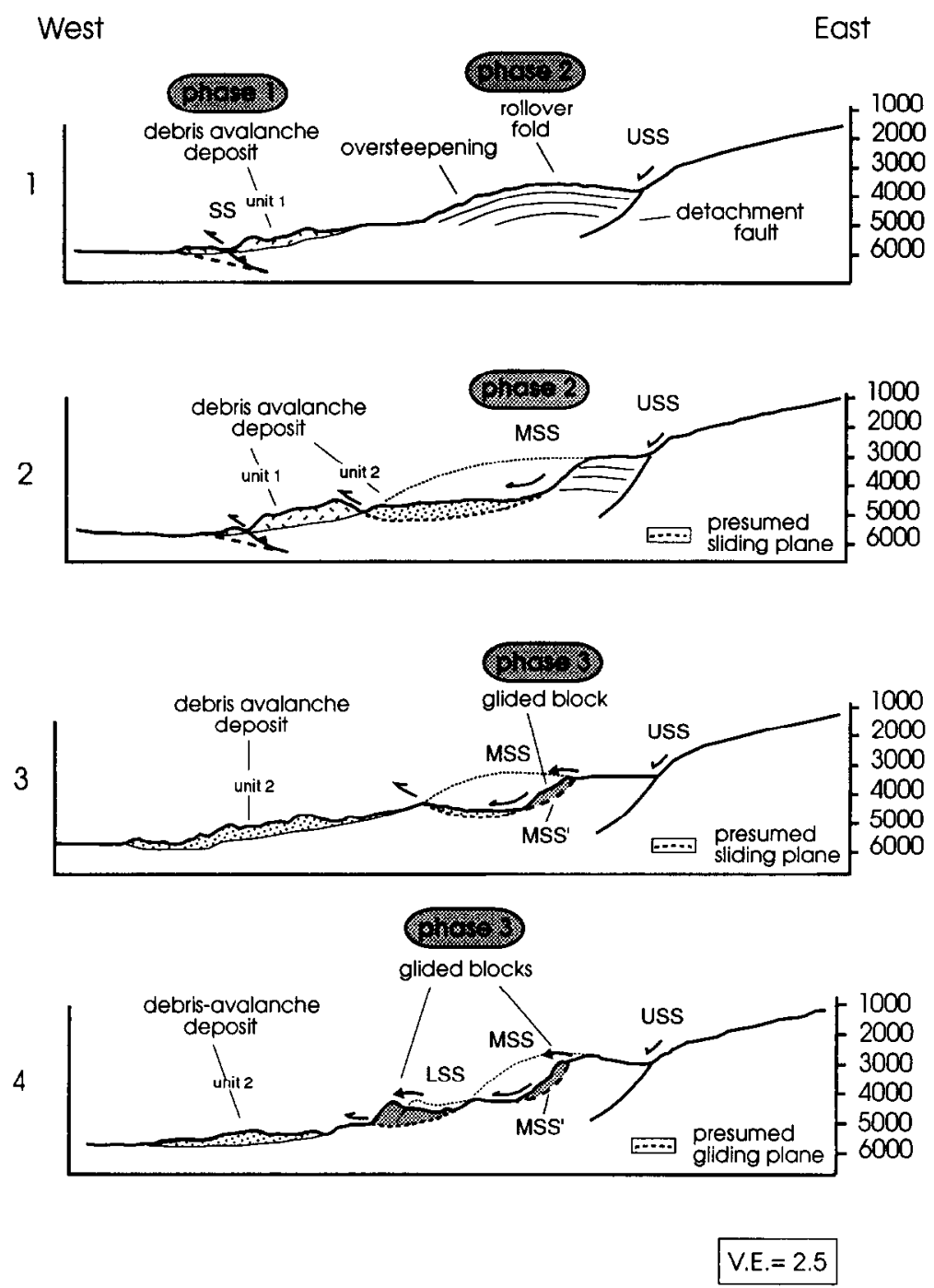

Fig. 15. Parallel E-W bathymetric sections, showing the different stages of instability along the slope. From north to south, these sections are also supposed to represent the chronological deformation of the slope. For location: see Fig. 5.

offered by the sediment strength. Slope instabilities can thus be the result of stress increases, sediment strength reduction, or a combination of both (Coleman and Prior, 1988; Lee et al., 1991). The two major factors generally invoked as responsible for slope instabilities are:

- A downslope stress increase, by external load or by basal unload. An external load results from slope angle steepening, occurring by tectonic effect or by high rates of sedimentation. Nevertheless, earthquakes could also induce a direct loading on the sea floor. A basal unload may result from the subduction of a negative oceanic asperity, as a graben.

- An excess of pore water pressure, which reduces the effective normal stress on the failure plane and consequently reduces the shearing resistance. The result is a direct decrease in stability. 


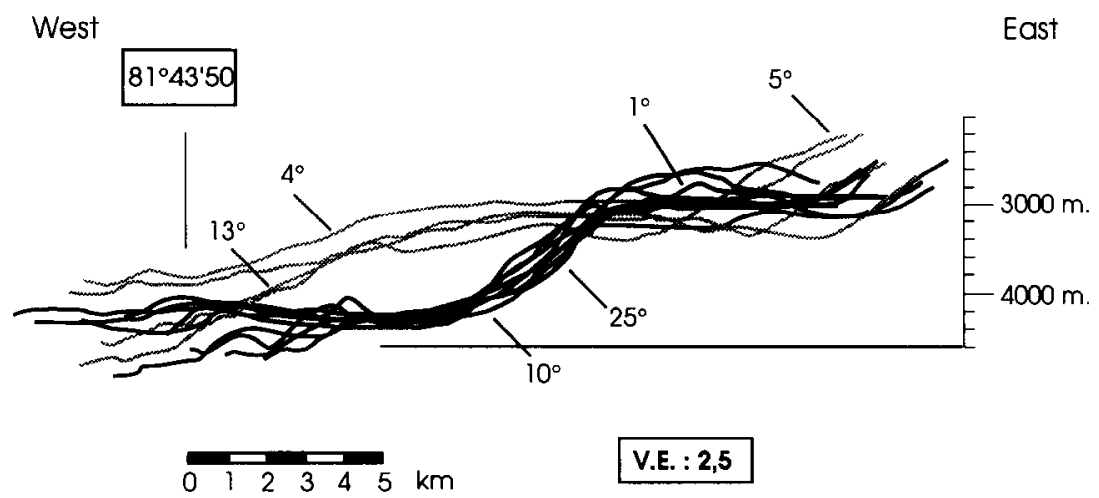

Fig. 16. Superposition of E-W bathymetric sections conducted from north to south on the middle and upper slope. Grey: sections located north of the E-W trending section of the MSS. Black: sections located south of the E-W trending section of the MSS. The numbers indicate the mean value of the slope gradient of each part of the continental slope.

The excess of pore pressure can result from allochthonous fluid accumulation, from high rates of sedimentation or from carthquakes.

\subsection{Sedimentary loading}

As revealed by the datings of sampled rocks collected along the MSS (Figs. 7 and 12), the E-W trending section of the MSS exhibits $500 \mathrm{~m}$ of Quaternary to Plio-Quaternary mudstones. Along the N-S trending section, however, the Quaternary sequence gets thinner and disappears at the south ending of the MSS (De Wever et al., 1995). The seaward flank of the rollover fold is therefore assumed to be mainly composed of Quaternary sediments, which are able to induce a sedimentary loading in association with the anticline deformation of the middle slope.

\subsection{Localized slope angle steepening}

As shown on Fig. 16, a series of parallel bathymetric sections across the middle and the upper slope clearly show an oversteepening of the middle slope. The arch of the middle slope observed north of the E-W section of the MSS has slope gradients varying from $4^{\circ}$ in the north to $13^{\circ}$ in the south, whereas the slope gradient along the MSS ranges between $20^{\circ}$ and $30^{\circ}$. From east to west of the USS, the upper and middle slope displays a slope gradient of $5^{\circ}$ and $1^{\circ}$, respectively. The middle slope has thus rotated some $4^{\circ}$ landward by rol- lover deformation along the USS (Bourgois et al., 1993). The seaward flank of the stable part of the rollover shows an oversteepening, with a slope gradient of $13^{\circ}$. At this location, slope failure has occurred by oversteepening of the middle slope for slope gradients greater than $13^{\circ}$ (Duperret et al., 1993). The anticline deformation of the middle slope and the subsequent oversteepening of its seaward flank is related to the motion of the middle slope area along the detachment fault which merges at the USS (Bourgois et al., 1993) (Fig. 12).

\subsection{Unloading by the subduction of oceanic depression}

The subduction of negative oceanic asperities may induce slope failure due to basal unloading within the upper plate. Von Huene et al. (1989) stated that the detachment fault merging at the USS penetrates the upper plate down to a depth of $5 \mathrm{~km}$. As shown in Fig. 14, the upper slope displays a number of recent normal faults which cut the Quaternary sequence. The faults extend down to a depth of about $2 \mathrm{~km}$, and thus appear to be more superficial than the detachment fault. The occurrence of a deep detachment fault may be explained by the existence of a large graben located within the oceanic crust subducted below the continental plate (Fig. 14). This graben may possibly contribute to the initiation of a deep detachment fault within the continental plate by 
basal unloading. Unfortunately, the oceanic crust is no longer traceable below the MSS due to the limited penetration depth of the seismic sources.

\subsection{Earthquakes}

The direct link between earthquakes and turbidites emplacement or submarine slope instabilities has been widely described (e.g. Prior and Coleman, 1984; Keefer, 1994). Earthquakes have two effects on the sediments of the slope (Hampton et al., 1978). Firstly, they induce horizontal and vertical acceleration stresses, which produce a direct loading on the sediment. Secondly, they also induce a potential buildup of fluid pressure in the sediment (Egan and Sangrey, 1978). Each seismic cycle is characterized by four distinct phases: (1) elastic strain accumulation, (2) possible preseismic anelastic deformation, (3) main shock rupture and energy release and (4) decelerating afterslip (Sibson, 1986, 1989). Most of the brittle deformation occurs primarily during the high-strain rate of the third phase. The slow processes, such as fracture sealing and healing by fluid transfer, as well as mineralogic alteration occur largely during the low-strain rates of the phases 1,2 and 4 . The seismic energy produced during phase 3 thus appears as a major triggering factor for fracturation. The numerous meso-scale joints observed along the MSS, could partly result of repeated shocks due to seismic activity in relation with active subduction.

\subsection{Excess of pore water pressure}

The occurrence of a wide range of cold seeps and related living biological communities at the bend of the MSS indicates a local excess of pore water pressure. According to Sibson (1989, 1990), fluid flow and fluid increase is induced along a fault due to the modulation of the fluid pressure during the earthquake stress cycle. Increasing fluid pressure can therefore be cyclically generated along the faults (Sibson, 1990; Chester et al., 1993). Sibson $(1990,1992)$ argues that in convergent tectonic settings, extreme fault-valve behaviour is likely to exist. Faults thus act as pumps or valves between two different hydrologic systems, by creat- ing an upward discharge path from the overpressured parts of the crust. A fault-valve behaviour along the pre-existing $\mathrm{E}-\mathrm{W}$ trending system of the margin could therefore recharge faults with fluids and may thus explain the fluid buildup along the MSS, which then discharges through dense sets of fractures and joints along the scarp. The slope failure leading to the second debris-avalanche may thus be increased by local weakening of the middle slope due to such pressure fluid rise during the coseismic slip of a seismic stress cycle. This hypothesis is supported by the chemistry of barite deposits collected among the largest biological community of the MSS (Aquilina et al., 1992). Oxygen and sulfur isotopes of barites suggest that they precipitated at temperatures superior to $70^{\circ} \mathrm{C}$, related to a higher rate of fluid flow, that occurred during the main shock rupture of a seismic cycle (Aquilina et al., 1994).

\section{Conclusions}

Extensive mapping of the northern Peruvian margin, using Seabeam and Hydrosweep multibeam echosounder data in combination with deep-sea submersible observations has allowed a better definition of the processes of large-scale polyphase submarines slides observed in the area. The main results of this study are:

(1) The occurrence of three distinctive slopefailure types, which are assume to be related to three main phases.

- The first phase of slope failure is documented by a debris-avalanche deposit located on the lower slope and on the landward part of the trench. It is cut by the trench scarp (TS) and covers the trench floor over a distance of $5 \mathrm{~km}$. The deposits originate from the northern wall of the wide valley located northward along the upper slope. The origin of the debris-avalanche is not completely clear. Nevertheless, the seismic energy released during the earthquake appears to be the most probable factor of failure.

- The second phase of slope failure is characterized by a debris-avalanche, marked by a semicrescent-shaped head scar (MSS) and a hummocky shaped deposit covering the lower slope and 
extending down over a distance of $10 \mathrm{~km}$ on the trench. The volume of rocks voided from the middle slope during this event is estimated to some $250 \mathrm{~km}^{3}$. Intensive coverage by deep-sea observations and seismics led to assume that this second phase of slope failure is mainly due to an oversteepening of the middle slope for a slope gradient greater than $13^{\circ}$. The oversteepening is induced by rollover deformation of the middle slope along a detachment fault merging upslope. The detachment fault might be initiated by the subduction of an oceanic asperity, such as a graben which is able to produce a basal unloading. The failure has been increased by an excess of pore water pressure within the middle slope sediments, which is assumed to be dependant on the lithostatic pressure due to sedimentary loading and on the seismic energy. Finally, the seismic energy produced during coseismic slip appears as a major factor for fracturation and fluid buildup along the area previously weakened by folding.

- The third phase of slope failure is characterized by a translational sliding block and by a toppling block. The blocks present a volume of some $6 \mathrm{~km}^{3}$ and $13 \mathrm{~km}^{3}$, respectively, and appear above the morphological features left by the second debris avalanche, indicating that they occurred later. Their volumes clearly show that this third event of slope failure is much less important than the first two. The gliding blocks display a different sliding motion, and are mainly induced by the local steepening of the source area, as shown by the MSS' which is gliding along the steepest part of the MSS.

(2) A major difference has been noted between the scar of the debris-avalanche (MSS) and the upslope scarp which delineates the major detachment fault of the margin (USS). The USS either appears as a creeping fault with a thick cover of pelagic sedimentation or as a present inactive fault, which has induced a general deformation of the middle slope by rollover. The MSS is marked by small cliffs with fresh outcrops illustrating the freshness of the scarp, and a dense net of joints and fractures which documents a debris avalanche by catastrophic failure.

(3) The three sliding phases display one common particular characteristic. They occur along the same $\mathrm{N} 230^{\circ}$ trend. This trend differs from the E-W oriented line of maximum slope gradient. This suggests that the slides may be controlled by the $\mathrm{N} 80^{\circ}$ orientation of the subducting Nazca plate.

(4) In the north of the lower slope, a system of $\mathrm{N}-\mathrm{S}$ ridges and valleys could represent an incipient accretionary prism. As the restricted accretionary prism seems to be partially buried by the first sliding deposit, this indicates that the sliding due to the rollover fold of the middle slope took place after the compressive deformation of the lower slope. This suggests that a compressive tectonic regime has occurred at the edge of the northern Peruvian margin before the present-day extensive regime. They may be related to the compressive state of stress within the subducted Nazca plate, as deduced from seismological data, and to the extensive state of stress obscrved along the upper part of the upper plate, as indicated by the normal faults. They thus document the paradox between the compressive regime in the lower plate and the extensional regime in the upper part of the upper plate. These features illustrate a situation which has been found in several subduction zones (L.D. Kulm, pers. commun., 1994).

(5) Sliding process is mainly related to extensive tectonics along the upper plate. Nevertheless, the whole study evidences some imprints related to the subducting plate:

- Polyphased slides are located along a particular emplacement of the upper plate where the plate slip vector is partitioning into roughly orthogonal Benioff zone slip in the south, and dextral strikeslip vector faulting in the north.

- The triggering factors are assumed to provide from a combination of earthquakes and the subduction of oceanic asperities, related to subduction processes.

- The resulting sliding trends are therefore slantwise oriented $\left(\mathrm{N} 230^{\circ}\right)$, along a general $\mathrm{E}-\mathrm{W}$ slope gradient.

\section{Acknowledgements}

The SEAPERC and the NAUTIPERC cruises were supported by IFREMER, INSU-CNRS and the 
Bundesministerium für Forschung und Technologie (Bonn). We are grateful to the captain and the crew of the R/V Charcot, R/V Nadir and the Nautile team for their efficient work and to the Peruvian navy, the IFEA and the French Embassies in Lima and Quito for their help. We also thank GEOMAR for the participation of J. Bourgois on the Sonne 78 cruise, and the use of the hydrosweep bathymetric data of this cruise.

We are much indebted to Christian De Muizon from IFEA in Lima for obtaining geologic and bathymetric data from PERU HIDRONAV, and to Serge Monti from IFREMER for supervising the bathymetric compilation of Seabeam, Hydrosweep and Peruvian Navy data. The analysis of seismological data greatly benefited from extensive discussions with Michel Sébrier and Frédéric Ego from Orsay University and Jacques Deverchère from Villefranche Observatory. Comments by Tine Missiaen from RCMG in Gent were very helpful in improving an earlier version of this paper. We thank them for their time and courtesy. The constructive remarks and very helpful suggestions of L.D. Kulm and A.I. Rees were greatly appreciated.

This work was supported by the INSU through the IST program. A. Duperret is a beneficiary of a grant from the French Ministry of Research and National Education.

\section{References}

Aquilina, L., Dia, A.N., Boulègue, J., Fouillac, A.-M., Suess, E., Von Breymann, M.T. and Bourgois, J., 1992. Geochemistry of barite and carbonate deposits associated with fluids vents in the Peru convergent margin off Paita. EOS, Trans. Am. Geophys. Union, Spring Meet. Suppl., $73(14): 153$.

Aquilina, L., Dia, A.N., Boulègue, J., Bourgois, J., Cros, P. and Fouillac, A.-M., 1994. Geochemistry of fluid and solid samples from convergent margin off Peru: Implications for fluid circulation within subduction zones. Geochim. Cosmochim. Acta, submitted.

Aubouin, J., Bourgois, J. and Azema, J., 1984. A new type of active margin: The convergent-extensional margin, as exemplified by the middle America trench of Guatemala. Earth Planet. Sci. Lett., 87: 111-126.

Barazangi, M. and Isacks, B.L., 1976. Spatial distribution of earthquakes and subduction of the Nazca plate beneath South America. Geology, 4: 686-692.

Bevis, M. and Isacks, B.L., 1984. Hypocentral trend surface analysis: probing the geometry of Benioff zones. J. Geophys. Res., 89: 6153-6170.

Boinet, T., Bourgois, J., Mendoza, H. and Vargas, R., 1985. Le poinçon de Pamplona (Colombie): un jalon de la frontière méridionale de la plaque Caraïbe. Bull. Soc. Geol. Fr., 8(1), 3: 403-413.

Boulègue, J., Beneditti, E.L., Dron, D., Mariotti, A. and Létolle, R., 1987. Geochemical and biogeochemical observations on the biological communities associated with fluid venting in Nankai Trough and Japan Trench subduction zones. Earth Planet. Sci. Lett., 83: 343-355.

Bourgois, J., Huchon, P. and Pautot, G., 1990. Tectonics of the Peru active margin. In: J. Aubouin and J. Bourgois (Fditors), Tectonics of the Circum-Pacific Continental Margins. Proc. 28th Int. Geol. Cong. (Washington, D.C.) pp. 77-137.

Bourgois, J., Lagabrielle, Y., De Wever, P. and Nautiperc Team, 1993. Tectonic history of the northern Peru convergent margin during the past $400 \mathrm{ka}$. Geology, 21: 531-534.

Bourgois, J., Pautot, G., Bandy, W., Boinet, T., Chotin, P., Huchon, P., Mercier de Lepinay, B., Monge, F., Monlau, J., Pelletier, B., Sosson, M. and Von Huene, R., 1986. Régime tectonique de la marge andine convergente du Pérou (Campagne Seaperc du N/O. J. Charcot, Juillet 1986). C.R. Acad. Sci. Paris, 303, Sér. II, 17: 1599-1604.

Bourgois, J., Pautot, G., Bandy, W., Boinet, T., Chotin, P., Huchon, P., Mercier de Lepinay, B., Monge, F., Monlau, J., Pelletier, B., Sosson, M. and Von Huene, R., 1988. Seabeam and seismic reflection imaging of the tectonic regime of the Andean continental margin off Peru $\left(4^{\circ} S\right.$ to $\left.10^{\circ} \mathrm{S}\right)$. Earth Planet. Sci. Lett., 87: 111-126.

Cadet, J.P., Kobayashi, S., Lallemand, S., Jolivet, L., Aubouin, J., Boulègue, J., Dubois, J., Hotta, H., Ishii, T., Konishi, K., Niitsuma, N. and Shimamura, H., 1987. Deep scientific dives in the Japan and Kuril trenches. Earth Planet. Sci. Lett., 83: 313-328.

Chase, C.G., 1978. Plate kinematics: The Americas, East Africa, and the rest of the world. Earth Planet. Sci. Lett., 37: 355-368.

Chester, F.M., Evans, J.P. and Biegel, R.L., 1993. Internal structure and weakening mechanisms of the San Andreas fault. J. Geophys. Res., 98(B1): 771-786.

Cochonat, P., Lenat, J.F., Bachelery, P., Boivin, P., Cornaglia, B., Deniel, C., Labazuy, P., Le Drezen, E., Lipman, P., Ollier, G., Savoye, B., Vincent, P. and Voisset, M., 1990. Importance des dépôts gravitaires dans la mise en place d'un système volcano-sédimentaire sous-marin (Volcan de la Fournaise, Ile de la Réunion). C.R. Acad. Sc. Paris, 311, Sér. II, pp. 679-686.

Coleman, J.M. and Prior, D.B., 1988. Mass wasting on continental margins. Ann. Rev. Earth Planet. Sci., 16: 101-119.

De Mets, C., Gordon, R.G., Argus, G.F. and Stein, S., 1990. Current plate motions. Geophys. J. Int., 101: 425-478. 
De Vries, T.J., 1988. The geology of late Cenozoic marinc terraces (tablazos) in northwestern Peru. J. S.Am. Earth Sci., 1(2): 121-136.

De Wever, P., Bourgois, J., Caulet, J.P., Fourtanier, E., Barron, J. and Dumitrica, P., 1995. Stratigraphic significance of siliceous microfossils collected during NAUTIPERC dives (off Peru, $5^{\circ}-6^{\circ} \mathrm{S}$ ). Mar. Micropaleontol., 24: 287-305.

Dewey, J.F. and Lamb, S.H., 1992. Active tectonics of the Andes. Tectonophysics, 205: 79-95.

Dia, A.N., Aquilina, L., Boulègue, J., Bourgois, J., Suess, E. and Torres, M., 1993. Origin of fluids and related-barite deposits at vent sites along the Peru convergent margin. Geology, 21: 1099-1102.

Duperret, A., Lagabrielle, Y. and Bourgois, J., 1993. Résultats des plongées du Nautile sur la marge continentale du Pérou à $5^{\circ} 40^{\prime} \mathrm{S}$ : étude de la zone d'arrachement d'un mégaglissement sous-marin (campagne Nautiperc, 1991). C.R. Acad. Sci. Paris, 303, Sér. II, 17: 1599-1604.

Dziewonsky, A.M., Ekström, G., Woodhouse, J.H. and Zwart, G., 1981-1992. Determination of Centroid momemt tensor solutions. Phys. Earth Planet. Inter.

Egan, J.A. and Sangrey, D.A., 1978. Critical state model for cyclic load pore pressure. Am. Soc. Civ. Eng. Spec. Conf. Earthquake Eng. Soil Dynamics. (Pasadena, CA.)

Hampton, M.A., Bouma, A.H., Carlson, P.R., Molnia, B.F., Clukey, E.C. and Sangrey, D.A., 1978. Quantitative study of slope instability in the gulf of Alaska. Offshore Technol. Conf., 10th Annu. OTC. (Houston, TX.)

Holcomb, R. and Searle, R., 1991. Large landslides from oceanic volcanoes. Mar. Geotech., 10: 19-32.

Hussong, D.M. and Wipperman, 1981. Vertical movement and tectonic erosion of the continental wall of the Peru-Chile trench near $11^{\circ} 30^{\prime} \mathrm{S}$ latitude, Nazca plate: Crustal formation and Andean convergence. Geol. Soc. Am. Mem., 154: 509-524.

Isacks, B.L. and Molnar, P., 1971. Distribution of stresses in the descending lithosphere from a global survey of focalmechanism solutions of mantle earthquakes. Rev. Geophys. Space Phys., 9: 103-174.

Keefer, D.K., 1994. The importance of earthquake-induced landslides to long-term slope erosion and slope-failure hazards in seismically active regions. Geomorphology, 10: 265-284.

Kulm, L.D., Dymond, J., Dasch, E.J., Hussong, D.M. and Roderick, R., 1981. Nazca plate: Crustal formation and Andean convergence. Geol. Soc. Am. Mem., 154, 824 pp.

Kulm, L.D., Sucss, E. and Thornburg, T.M., 1984. Dolomites in organic-rich muds of the Peru forearc basins: Analogue to the Monterey formation. In: R.E. Garrison et al. (Editors), Dolomites of the Monterey Formation and Other Organic-rich Units. Pac. Sect. SEPM Spec. Publ., 41: $29-47$.

Kulm, L.D., Thornburg, T.M., Suess, E., Resig, J. and Fryer, P., 1988. Clastic, diagenetic and metamorphic lithologies of a subsiding continental block: Central Peru forearc. Proc. ODP, Init. Rep., 112: 91-107.

Lagabrielle, Y., Duperret, A. and Bourgois, J., 1992. In-situ structural observations along the inner slope of the Peru trench: Preliminary results of the Nautiperc cruise with the submersible Nautile. EOS, Am. Geophys. Union Spring Meet. (Montreal.) Abstr., 73: 152.

Lallemand, S.E., Schnurle, P. and Manoussis, S., 1992. Reconstruction of subduction zone paleogeometries and quantification of upper plate material losses caused by tectonic erosion. J. Geophys. Res., 97: 217-239.

Le Pichon, X., Iiyama, T., Boulègue, J., Charvet, P., Faure, M., Kano, K., Lallemant, S., Okada, H., Rangin, C., Taira, A., Urabe, T. and Uyeda, S., 1987. Nankai Trough and Zenisu Ridge: a deep-sea submersible survey. Earth Planet. Sci. Lett., 83: 285-299.

Lee, H.J., Schwab, W.C., Edwards, B.D. and Kayen, R.E., 1991. Quantitative controls on submarine slope failure morphology. Mar. Geotechnol., 10: 143-157.

Lénat, J.F., Vincent, P. and Bachélery, P., 1989. The off-shore continuation of an active basaltic volcano: Piton de la fournaise (Reunion island, Indian Ocean); structural and geomorphological interpretation from seabeam bathymetry. J. Volcanol. Geothermal Res., 36: 1-36.

Li, C. and Clark, A.L., 1991. SeaMarc II study of a giant submarine slump on the northern Chile continental slope. Mar. Geotechnol., 10: 257-268.

Lipman, P.W., Normark, W.R., Moore, J.G., Wilson, J.B. and Gutmacher, C.E., 1988. The giant submarine Alika debris slide, Mauna Loa, Hawaii. J. Geophys. Res., 93: 4279-4299.

Macharé, J. and Ortlieb, L., 1993. Coastal neotectonics in Pcru: subduction regime and quaternary vertical motions. 2nd Int. Symp. Andean Geodyn. (Oxford, 21-23 Sept. 1993.) Abstr., pp. 107-110.

Mercier, J.L., Sebrier, M., Lavenu, A., Cabrera, J., Bellier, O., Dumont, J.F. and Machare, J., 1992. Changes in the tectonic regime above a subduction zone of Andean type: The Andes of Peru and Bolivia during the Pliocene-Pleistocene. J. Geophys. Res., 97(B8): 11945-11982.

Miller, J., Hussong, D. and Von Huene R., 1986. The Peru continental margin, record section 3. In: $R$. von Huene (Editor), Seismic Images of Modern Convergent Margin Tectonic Structure. AAPG Stud. Geol., 16: 32-33.

Minster, J. and Jordan, T., 1978. Present-day plate motions. J. Geophys. Res., 83(B11): 5331-5354.

Moore, J.C. and Vrolijk, P., 1992. Fluids in accretionary prisms. Rev. Geophys., 30: 113-135.

Moore, J.G., Clague, D.A., Holcomb, R.T., Lipman, P.W., Normark, W.R. and Torresan, M.E., 1989. Prodigious submarine slides on the Hawaiian Ridge. J. Geophys. Res., 94: $17,465-17,484$.

Olu, K., Duperret, A., Sibuet, M., Foucher, J.-P., FialaMedioni, A. and Bourgois, J., 1994a., Ecology of cold seep communities on the northern Peruvian active margin. 7th Deep-sea Biol. Symp. (29 Sept.-4 Oct. 1994, Heraklion, Crete.) Abstr.

Olu, K., Duperret, A., Sibuet, M., Foucher, J.-P. and FialaMedioni, A., 1994b. Structure and distribution of cold seep communities on the Peruvian margin active margin controlled by geological context and fluid patterns. Mar. Ecol. Prog. Ser., submitted. 
Pardo-Casas, F. and Molnar, P., 1987. Relative motion of the Nazca (Farallon) and South America plate since late Cretaceous times. Tectonics, 6: 233-248.

Prior, D.B. and Coleman, J.M., 1984. Submarine slope instability, In: D. Brundsen and D.B. Prior (Editors), Slope Instability. Wiley, New York, pp. 419-455.

Scholl, W.D., Von Huene, R., Vallier, T.L. and Howell, D.G., 1980. Sedimentary masses and concepts about tectonic processes at underthrust ocean margins. Geology, 8: 564-568.

Schwab, W.C., Danforth, W.W., Scanlon, K.M. and Masson, D.G., 1991. A giant submarine slope failure on the northern insular slope of Puerto Rico. Mar. Geol., 96: 237-246.

Sébrier, M. and Soler, P., 1991. Tectonics and magmatism in the Peruvian Andes from Oligocene time to Present. In: R.S. Harmon and C.W. Rapela (Editors), Andean Magmatism and its Tectonic Setting. Geol. Soc. Am. Spec. Pap., 265: 259-278.

Shepherd, G.L. and Moberly, R., 1975. Southern extension of the Dolores-Guayaquil Megashear across the continental margin of northwest Peru and the Gulf of Guayaquil. EOS, Trans. Am. Geophys. Union, 56: 442.

Shepherd, G.L. and Moberly, R., 1981. Coastal structure of the continental margin, Northwest Peru and Southwest Ecuador. In: L.D. Kulm, J. Dymond, E.J. Dasch and D.M. Hussong (Editors), Nazca Plate: Crustal Formation and Andean Convergence. Geol. Soc. Am. Mem., 154: 351-391.

Sibson, R.H., 1989. Earthquakes faulting as a structural process, J. Struct. Geol., 11: 1-14.

Sibson, R.H., 1990. Conditions for fault valve behaviour. In: R.J. Knipe and E.H. Rutter (Editors), Deformation Mechanisms, Rheology and Tectonics. Gcol. Soc. Spcc. Publ., 54: 15-28.

Sibson, R.H., 1992. Implications of fault-valve behaviour for rupture nucleation and reccurence. Tectonophysics, 211: 283-293.

Sibuet, M., Juniper, K.S. and Pautot, G., 1988. Cold-seep benthic communities in the Japan subduction zones: Geological control of community development. J. Mar. Res., 46: 333-348.

Sosson, M., Bourgois, J. and Mercier de Lepinay, B., 1994.
Seabeam and deep-sea submersible Nautile surveys in the Chiclayo canyon off Peru ( $\left.7^{\circ} \mathrm{S}\right)$ : Subsidence and subductionerosion of the andean type convergent margin since Pliocene time. Mar. Geol., 118: 237-256.

Stauder, W., 1973, Mechanisms and spatial distribution of Chilean earthquakes with relation to subduction of the oceanic plate. J. Geophys. Res., 74: 5033-5061.

Stauder, W., 1975. Subduction of Nazca plate under Peru as evidenced by focal mechanisms and by seismicity. J. Geophys. Res., 80: 1053-1064.

Suess, E., Carson, B., Ritger, S., Moore, J.C., Jones, M.L., Kulm, L.D. and Cochrane, G.R., 1985. Biological communities at vent sites along the subduction zone off Oregon. In: M.L. Jones (Editor), The Hydrothermal Vents of the Eastern Pacific: An Overview. Biol. Soc. Wash. Bull., 6: 474-484.

Suess, E., Von Huene, R. and Leg 112 Shipboard Scientists, 1988. Ocean Drilling program, leg 112, Peru continental margin: Part 2, Sedimentary history and diagenesis in a coastal upwelling environment. Geology, 16: 939-938.

Thornburg, T.M. and Kulm, L.D., 1981. Sedimentary basins of the Peru continental margin: Structure, stratigraphy and Cenozoic tectonics from $6^{\circ} \mathrm{S}$ to $16^{\circ} \mathrm{S}$ latitude. In: L.D. Kulm, J. Dymond, E.J. Dasch and D.M. Hussong (Editors), Nazca Plate: Crustal Formation and Andean Convergence. Geol. Soc. Am. Mem., 154: 393 422.

USGS-NEIC, 1988. World Data Center for Seismology. Listing years from 1977 to 1988. U.S. Dep. Interior.

Von Huene, R. and Miller, J., 1988. Migrated multichannel seismic-reflection records across the Peru continental margin. Proc. ODP, Init. Rep., 112: 109-124.

Von Hucnc, R, and Scholl, D.W., 1991. Observations at convergent margins concerning sediment subduction, subduction erosion and the growth of continental crust. Rev. Geophys., 29: 279-316.

Von Huene, R., Bourgois, J., Miller, J. and Pautot, G., 1989. A large tsunamogenic landslide and debris flow along the Peru trench. J. Geophys. Res., 94(B2): 1703-1714.

Von Huene, R., Suess, E. and Leg 112, Shipboard Scientists, 1988. Ocean Drilling Program, leg 112, Peru continental margin: Part 1, Tectonic history. Geology, 16: 934-938. 